\title{
Lead toxicity in plants
}

\author{
Pallavi Sharma and Rama Shanker Dubey*
}

Department of Biochemistry, Faculty of Science, Banaras Hindu University Varanasi-221005, India. *Corresponding author: rsd@bhu.ac.in

Contamination of soils by heavy metals is of widespread occurrence as a result of human, agricultural and industrial activities. Among heavy metals, lead is a potential pollutant that readily accumulates in soils and sediments. Although lead is not an essential element for plants, it gets easily absorbed and accumulated in different plant parts. Uptake of Pb in plants is regulated by $\mathrm{pH}$, particle size and cation exchange capacity of the soils as well as by root exudation and other physico-chemical parameters. Excess $\mathrm{Pb}$ causes a number of toxicity symptoms in plants e.g. stunted growth, chlorosis and blackening of root system. $\mathrm{Pb}$ inhibits photosynthesis, upsets mineral nutrition and water balance, changes hormonal status and affects membrane structure and permeability. This review addresses various morphological, physiological and biochemical effects of $\mathrm{Pb}$ toxicity and also strategies adopted by plants for $\mathrm{Pb}$-detoxification and developing tolerance to $\mathrm{Pb}$. Mechanisms of $\mathrm{Pb}$-detoxification include sequestration of $\mathrm{Pb}$ in the vacuole, phytochelatin synthesis and binding to glutathione and aminoacids etc. Pb tolerance is associated with the capacity of plants to restrict $\mathrm{Pb}$ to the cell walls, synthesis of osmolytes and activation of antioxidant defense system. Remediation of soils contaminated with $\mathrm{Pb}$ using phytoremediation and rhizofiltration technologies appear to have great potential for cleaning of $\mathrm{Pb}$-contaminated soils.

Key words: antioxidant defense system, detoxification, lead, osmolytes, toxicity, phytochelatin, phytoremediation, rhizofiltration, tolerance

Toxicidade de chumbo em plantas: A contaminação de solos por metais pesados é de ocorrência generalizada como resultado das atividades humana, agrícola e industrial. Entre os metais pesados, o chumbo $(\mathrm{Pb})$ é um poluente potencial que, prontamente, se acumula nos solos e sedimentos. Apesar de não ser um elemento essencial para as plantas, é facilmente absorvido e acumulado em diferentes partes delas. A absorção de $\mathrm{Pb}$ é regulada pelo $\mathrm{pH}$, tamanho de partículas e capacidade de troca de cátions dos solos, assim como pela exsudação e outros parâmetros físicoquímicos. Excesso de $\mathrm{Pb}$ causa vários sintomas de toxicidade em plantas, por exemplo: redução de crescimento, clorose e escurecimento do sistema radicular. Pb inibe a fotossíntese, altera a nutrição mineral e o balanço hídrico, modifica o estado hormonal e afeta a estrutura e permeabilidade da membrana. Esta revisão aborda vários efeitos morfológicos, fisiológicos e bioquímicos da toxicidade de $\mathrm{Pb}$ e também as estratégias adotadas pelas plantas para a destoxificação e o desenvolvimento de tolerância ao $\mathrm{Pb}$. Mecanismos de destoxificação ao $\mathrm{Pb}$ incluem o seqüestro de $\mathrm{Pb}$ no vacúolo, síntese de fitoquelatinas e o acoplamento a glutationa e aminoácidos, etc. A tolerância ao $\mathrm{Pb}$ está associada à capacidade das plantas a restringir o metal à parede celular, síntese de osmólitos, e ativação do sistema antioxidante de defesa. Remediação de solos contaminados com $\mathrm{Pb}$ usando as tecnologias de fitorremediação e rizofiltração parecem ter grande potencial para a limpeza de solos contaminados com esse metal pesado.

Palavras-chave: chumbo, destoxificação, fitoquelatina, fitorremediação, osmólitos, rizofiltração, sistema de defesa antioxidante, tolerância, toxicidade.

\section{INTRODUCTION}

Lead $(\mathrm{Pb})$ is one of the major heavy metals of the antiquity and has gained considerable importance as a potent environmental pollutant. Apart from the natural weathering processes, $\mathrm{Pb}$ contamination of the environment has resulted from mining and smelting activities, $\mathrm{Pb}$ containing 
paints, gasoline and explosives as well as from the disposal of municipal sewage sludges enriched in $\mathrm{Pb}$ (Chaney and Ryan, 1994). Despite regulatory measures adopted in many countries to limit $\mathrm{Pb}$ input in the environment, it continues to be one of the most serious global environmental and human hazards. As many of the $\mathrm{Pb}$ pollutants are indispensable for modern human life, soil contamination with $\mathrm{Pb}$ is not likely to decrease in the near future (Yang et al., 2000).

Significant increases in the $\mathrm{Pb}$ content of cultivated soils has been observed near industrial areas. $\mathrm{Pb}$ tends to accumulate in the surface ground layer and its concentration decreases with soil depth (de Abreu et al., 1998). It is easily taken up by plants from the soil and is accum ulated in different organs. $\mathrm{Pb}$ is considered a general protoplasmic poison, which is cumulative, slow acting and subtle. Soils contaminated with $\mathrm{Pb}$ cause sharp decreases in crop productivity thereby posing a serious problem for agriculture (Johnson and Eaton, 1980). The present review focuses on the sources of $\mathrm{Pb}$; its uptake and transport within plant; physiological, biochemical and ultrastructural changes due to $\mathrm{Pb}$ toxicity; $\mathrm{Pb}$ tolerance in plants as well as possible remediation measures for $\mathrm{Pb}$ contaminated soils.

Sources of lead: $\mathrm{Pb}$ is a major pollutant in both terrestrial and aquatic ecosystems. Besides natural weathering processes the main sources of $\mathrm{Pb}$ pollution are exhaust fumes of automobiles, chimneys of factories using $\mathrm{Pb}$, effluents from the storage battery, industry, mining and smelting of $\mathrm{Pb}$ ores, metal plating and finishing operations, fertilizers, pesticides and additives in pigments and gasoline (Eick et al., 1999). Figure 1 depicts various sources, which contribute to $\mathrm{Pb}$ pollution in the environment. Tetraethyl and tetramethyl $\mathrm{Pb}$ are added to gasoline to increase the octane rating. In urban areas automobile exhaust contributes substantially to the atmospheric pollution. $\mathrm{Pb}$ compounds are major pollutants emitted by automobiles. Plants growing near highways are usually exposed to more $\mathrm{Pb}$ than other localities. Sewage sludge containing large quantities of $\mathrm{Pb}$ and other metals is regularly discharged on to field and garden soils due to increasing trends in urbanization (Paivoke, 2002). Pb-affected soils contain $\mathrm{Pb}$ in the range of $400-800 \mathrm{mg} \mathrm{Kg}^{-1}$ soil whereas in industrialized areas the level may reach upto 1000 mg Pb. $\mathrm{Kg}^{-1}$ soil (Angelon and Bini, 1992). Half of the $\mathrm{Pb}$ containing particulate matter falls to the ground within 100 feet of roadways and is then washed away and dispersed in the atmosphere and may be carried a considerable distance by air movements before it is eventually deposited. The ac- cumulated $\mathrm{Pb}$ on the street and highways is transported to surface streams by rain water and consequently pollutes others surface waterways and soil (Laxen and Harrison, 1977). Compounds of $\mathrm{Pb}$ used as agricultural chemicals such as $\mathrm{Pb}$ arsenate, which is used as a pesticide, contaminate agricultural soils.

In a long term field experiment (41 years) involving regular application of mineral fertilizers to crops of sunflower or barley followed by oat-winter rye in rotation, revealed that the fertilizers increased the level of mobile forms of $\mathrm{Pb}$ in the soil and also its uptake by the crops (Stefanov et al., 1995). Mine water also transports a large amount of fine-grained sediments contaminated with $\mathrm{Pb}$ (Laxen and Harrison, 1977).

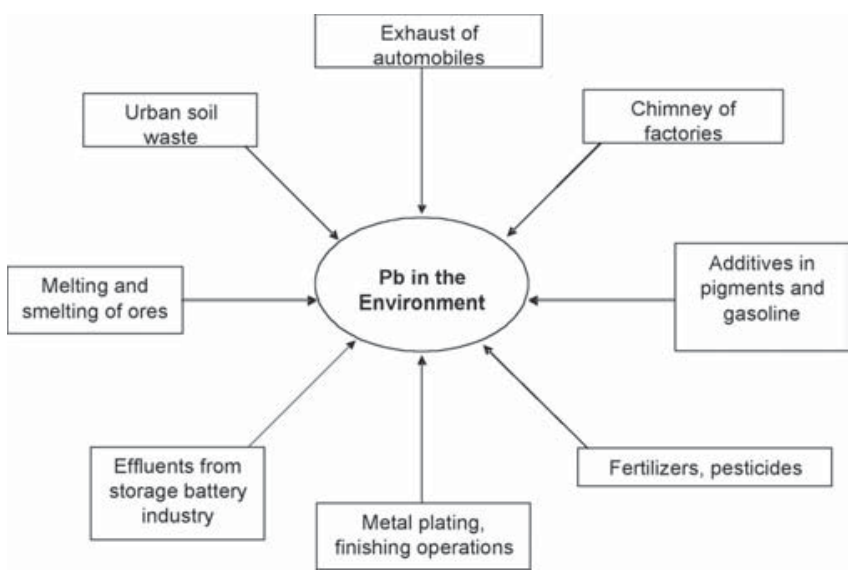

Figure 1. Sources of lead pollution in the environment.

Uptake, transport and localization: $\mathrm{Pb}$ is available to plants from soil and aerosol sources. $\mathrm{Pb}$ uptake studies in plants have demonstrated that roots have an ability to take up significant quantities of $\mathrm{Pb}$ whilst simultaneously greatly restricting its translocation to above ground parts (Lane and Martin, 1977). This notion was overturned by Miller and Koeppe (1971) who demonstrated that Zea mays L. plants could translocate and accumulate significant quantities of $\mathrm{Pb}$ in the leaves in a concentration dependent manner. The extent to which $\mathrm{Pb}$ enters plants via the leaves depends on the ability of leaves to absorb $\mathrm{Pb}$ from aerial sources, which in turn depends on the specific leaf morphology. Downy leaves absorb heavy metals from the atmosphere (Godzik, 1993). However it is agreed that the bulk of the $\mathrm{Pb}$ taken up by plants remains in the roots (Kumar et al., 1995). $\mathrm{Pb}$ accumulates in the surface layers of soils and therefore it is difficult to reliably measure the portion of soil $\mathrm{Pb}$ directly available to plants. Its availability depends highly on soil conditions. $\mathrm{Pb}$ binds to organic material 
in the soil. Soil particle size and cation exchange capacity as well as plant factors such as root surface area, root exudates, mycorrhization and rate of transpiration affect the availability and uptake of $\mathrm{Pb}$ (Davies, 1995). The absorption of $\mathrm{Pb}$ (as $\mathrm{Pb}$ ) in soil follows the Langmuir relation and increases with increasing pH between 3.0 to 8.5 (Lee et al., 1998). However Blaylock and coworkers (1997) reported that in soil with a $\mathrm{pH}$ between 5.5 and $7.5 \mathrm{~Pb}$ solubility is controlled by phosphate or carbonate precipitates and very little $\mathrm{Pb}$ is available to plants even if they have the genetic capacity to accumulate it. $\mathrm{Pb}$ in soil is classified as a weak Lewis acid, which implies a strong covalent character to many of the ionic bonds it forms in soils and plants. $\mathrm{Pb}$ present in the soil is nearly always tightly bound to organic or colloidal material or in a precipitated form, all of which serve to reduce the uptake of $\mathrm{Pb}$ by plant roots.

At the root surface $\mathrm{Pb}$ binds to carboxyl groups of mucilage uronic acids. Mucilage binding restricts metal uptake into the root and establishes an important barrier protecting the root system. Some of the bound metals are released when mucilage is biodegraded (Morel et al., 1986). Soil microorganisms may affect heavy metal availability by the process of biosorption, bioaccumulation and solubilization. It was shown by Marschner and coworkers (1996) that ectomycorrhiza could influence uptake, transport and toxicity of $\mathrm{Pb}$ in Norway spruce plants.

$\mathrm{Pb}$ retention in the roots is based on binding of $\mathrm{Pb}$ to ion exchangeable sites on the cell wall and extracellular precipitation, mainly in the form of $\mathrm{Pb}$ carbonate deposited in the cell wall. The addition of synthetic chelates, such as H-EDTA or EDTA, in combination with low $\mathrm{pH}$, effectively prevents cell wall retention of lead, making it available for translocation to shoots (Jarvis and Leung, 2002). After being taken up by roots, the localization of $\mathrm{Pb}$ is greater in roots than in other parts of the plants. $\mathrm{Pb}$ binds strongly to the carboxyl groups of the carbohydrates galacturonic acid and glucuronic acid in the cell wall, which restricts its transportation via apoplast (Rudakova et al., 1988). In general dicots accumulate significantly higher amounts of $\mathrm{Pb}$ in the roots than monocots (Huang and Cunningham, 1996). Pb transported from the soil to the root cells has to cross the root-cell plasma membrane. One possible transport pathway of $\mathrm{Pb}$ across the plasma membrane (PM) appears to be through PM cation channels, such as Ca-channels. A voltage gated Ca-channel in the root cell PM has been characterized using right-side-out PM vesicles isolated from roots of wheat and corn plants (Marshall et al., 1994; Huang et al., 1994). Huang and Cunningham (1996) found that $\mathrm{Pb}$ significantly inhibited voltage gated $\mathrm{Ca}$-channels activity in the PM of wheat roots. The inhibition of the $\mathrm{Ca}$-channel by $\mathrm{Pb}$ could arise from $\mathrm{Pb}$ blockage of the channel or due to competitive transport of $\mathrm{Pb}$ through the $\mathrm{Ca}$-channel. While monitoring $\mathrm{Pb}$ entry into isolated cells, Tomsig and Suszkiw (1991) observed permeation of $\mathrm{Pb}$ through $\mathrm{Ca}$-channels. These workers also found that voltage gated $\mathrm{Pb}$ transport was blocked by nifedipine (a Ca-channel blocker) and enhanced by BAY K8644 (a Cachannel agonist).

$\mathrm{Pb}$ moves predominantly into the root apoplast and thereby in a radial manner across the cortex and accumulates near the endodermis. The endodermis acts as a partial barrier to the movement of $\mathrm{Pb}$ between the root and shoot. This may in part account for the reports of higher accumulation of $\mathrm{Pb}$ in roots compared to shoots (Jones et al., 1973; Verma and Dubey, 2003). When rice (Oryza sativa L.) seedlings were raised in sand cultures for 10 and 20 days in nutrient medium containing $500 \mu \mathrm{M}$ and $1000 \mu \mathrm{M} \mathrm{Pb}\left(\mathrm{NO}_{3}\right)_{2}$, root growth was reduced by 22 to $42 \%$ and shoot growth by $25 \%$, whereas localization of absorbed $\mathrm{Pb}$ was 1.7 to 3.3 times higher in roots compared to shoots (table 1). The limited transport of $\mathrm{Pb}$ from roots to other organs is due to the barrier of the root endodermis. It appears that casparian strips of the endodermis are the major limiting factor restricting $\mathrm{Pb}$ transport across endodermis into the central cylinder tissue (Seregin and Ivanov, 1997). According to Lane and Martin (1977) the endodermis appears to act as a partial barrier since some of the $\mathrm{Pb}$ moves up through the vascular tissues and diffuses out into the surrounding tissues. This provides evidence that $\mathrm{Pb}$ moves into the symplast. That movement of $\mathrm{Pb}$ in the root is primarily via the apoplast is also supported by the report that a large proportion of $\mathrm{Pb}$ is readily extractable in water (Broyer et al., 1972). The possibility of symplastic transport of $\mathrm{Pb}$ has been demonstrated in onion roots and garden cress hypocotyls (Wierzbicka, 1987). Higher concentrations of $\mathrm{Pb}$ cause cell injury and disturb the barrier function of the plasmalemma as well as the selective permeability of the plasmalemma and tonoplast. Seregin and coworkers (2004) demonstrated that a significant amount of $\mathrm{Pb}$ was retained at the surface of plasmalemma rather than in the cell walls (Seregin et al., 2004). Pb enters the injured cells together with compounds such as the procion dyes, which do not enter the undamaged cells (Seregin et al., 2004).

The pattern of distribution of $\mathrm{Pb}$ in the roots considerably differs depending on whether the concentrations of $\mathrm{Pb}$ are lethal or non-lethal (Seregin et al., 2004). At lower concentra- 
tions, $\mathrm{Pb}$ ions predominantly flow in the apoplast, whereas at higher concentrations, the barrier function of plasmalemma is damaged and a greater amount of $\mathrm{Pb}$ enters into the cells.

In general, the apparent concentration of $\mathrm{Pb}$ in aerial parts of the plant decreases as the distance from the root increases. This occurs due to greater localization of $\mathrm{Pb}$ in cell walls of the root than in other parts of the plant. Further, binding of $\mathrm{Pb}$ occurs more in lignified rather than non-lignified tissues. Suchodoller (1967) found that in barley much of the applied $\mathrm{Pb}$ was retained in the root epidermis while a small amount could be detected in the vascular tissues. This suggests that the extent of localization of $\mathrm{Pb}$ in different tissues of the plant is also dependent on the plant species. In seeds, the testa prevents entry of $\mathrm{Pb}$ into the internal tissues until it is ruptured by the developing radicle. Once the testa is ruptured, $\mathrm{Pb}$ is taken up very rapidly, with notable exceptions occurring in the meristematic regions of the radicle and hypocotyls (Lane and Martin, 1977). In the cotyledons, $\mathrm{Pb}$ moves through the vascular tissues and tends to accumulate in discrete areas in the distal parts (Lane and Martin, 1977).

The content of $\mathrm{Pb}$ in various plant organs tends to decrease in the following order: roots $>$ leaves $>$ stem $>$ inflores cence $>$ seeds. However this order can vary with plant species (Antosiewicz, 1992). In onion (Allium cepa) plants, absorbed $\mathrm{Pb}$ is localized in highest concentration in the root tips followed by proximal parts of the root, while its lowest concentration is found in the root base (Michalak and Wierzbicka, 1998). Leaves differ in their abilities to accumulate $\mathrm{Pb}$ depending on age. Maximum $\mathrm{Pb}$ content is found in senescing leaves and least in young leaves (Godzik, 1993). Ultrastructural studies have revealed that variable amounts of $\mathrm{Pb}$ deposits are present mainly in the intercellular space, cell wall and vacuoles, whereas small deposits of this metal are seen in the ER, dictyosomes and dictyosome derived vesi- cles. The cell wall and vacuole together account for about 96 $\%$ of absorbed $\mathrm{Pb}$ (Wierzbicka and Antosiewicz, 1993). The fact that $\mathrm{Pb}$ is found in the ER and dictyosome is apparently related to metal secretion of the cell surface into the vacuole. A small quantity of $\mathrm{Pb}$ reaches nuclei, chloroplasts and mitochondria and exerts its toxic effects on these organelles. In leaf cells of Potamogeton spp. it was shown that the electrochemical potential gradients between cell vacuoles and the outside bathing solution ranged from -150 to -240 $\mathrm{mV}$ (Denny and Weeks, 1968) which could favour a passive influx of $\mathrm{Pb}$ into vacuoles during $\mathrm{Pb}$ treatment. Of particular interest is the invagination of the plasmalemma to form pinocytotic vacuoles in many plant species. In Stigeoclonium the formation of such vacuoles is important for the sequestration of excess metal ions, as these vacuoles could protect the cell contents from toxic effects of $\mathrm{Pb}$ (Silverberg, 1975). Sometimes, particularly in close proximity to the plasmodesmata, the larger $\mathrm{Pb}$ particles appear to occupy much of the volume of the cell wall. In the other regions where the cell wall is much thicker and more substantial, smaller $\mathrm{Pb}$ particles accumulate within the cell wall towards its periphery. The deposition of these smaller $\mathrm{Pb}$ particles occurs possibly through the action of pinocytotic vesicles (Ksiazek et al., 1984).

While considerable information is available on $\mathrm{Pb}$ distribution the cells of terrestrial plants, little is known about $\mathrm{Pb}$ localization in the cells of aquatic plants. Lemna minor L. (duck weed) plants when treated with $\mathrm{Pb}$ for one hour showed maximum concentration of $\mathrm{Pb}$ in small vacuoles (Samardakiewicz and Wozny, 2000). After 6 and $12 \mathrm{~h}$ of $\mathrm{Pb}$ treatment, the content of in cell walls gradually increased. The localization of $\mathrm{Pb}$ between vacuoles and cell walls possibly results due to redistribution of $\mathrm{Pb}$ and it reflects increased apoplastic transport (Samardakiewicz and Wozny, 2000).

Table 1. Lead content and lengths of roots and shoots of rice seedlings grown for 10 and 20 days in presence of $500 \mu \mathrm{M}$ and $1000 \mu \mathrm{M}$ $\mathrm{Pb}\left(\mathrm{NO}_{3}\right)_{2}$ in sand cultures.

\begin{tabular}{|c|c|c|c|c|c|}
\hline \multirow{2}{*}{$\begin{array}{l}\text { Age of } \\
\text { seedlings } \\
\text { (Days) }\end{array}$} & \multirow{2}{*}{$\begin{array}{l}\text { Concentration of } \mathrm{Pb} \\
\qquad(\mu \mathrm{M})\end{array}$} & \multicolumn{2}{|c|}{$\begin{array}{l}\text { Length } \\
(\mathrm{cm})\end{array}$} & \multicolumn{2}{|c|}{$\begin{array}{c}\mathrm{Pb} \text { content } \\
\left(\mu \mathrm{mol} \mathrm{Pb} \cdot \mathrm{g}^{-1} \mathrm{DW}\right)\end{array}$} \\
\hline & & Root & Shoot & Root & Shoot \\
\hline \multirow{3}{*}{$10 \mathrm{~d}$} & 0 & 8.84 & 9.23 & 0 & 0 \\
\hline & 500 & 6.92 & 8.84 & 0.16 & 0.06 \\
\hline & 1000 & 6.15 & 6.92 & 0.72 & 0.22 \\
\hline \multirow{3}{*}{$20 \mathrm{~d}$} & 0 & 11.92 & 17.69 & 0 & 0 \\
\hline & 500 & 9.23 & 16.15 & 0.80 & 0.38 \\
\hline & 1000 & 6.92 & 13.84 & 1.22 & 0.72 \\
\hline
\end{tabular}

From Verma and Dubey (2003) 
The presence of $\mathrm{Pb}$ in small vesicles in Lemna minor suggests that endocytosis plays an important role in $\mathrm{Pb}$ uptake in these plants.

Physiological, biochemical and ultrastructural effects of lead: The visual non-specific symptoms of $\mathrm{Pb}$ toxicity are rapid inhibition of root growth, stunted growth of the plant and chlorosis (Burton et al., 1984). When Pb enters inside the cells even in small amounts it produces a wide range of adverse effects on physiological processes. A generalized view of the effects of $\mathrm{Pb}$ toxicity on key physiological processes in plants is presented in figure 2 . $\mathrm{Pb}$ phytotoxicity leads to inhibition of enzyme activities, disturbed mineral nutrition, water imbalance, change in hormonal status and alteration in membrane permeability. These disorders upset normal physiological activities of the plant. At high concentrations $\mathrm{Pb}$ eventually may $\mathrm{Pb}$ to cell death (Ernst, 1998; Seregin and Ivanov, 2001). At the cellular level $\mathrm{Pb}$ inhibits the activities of enzymes containing sulphydryl (-SH) groups necessary for their activity (van Assche and Clijsters, 1990). Pb toxicity inhibits germination of seeds and retards growth of seedlings. $\mathrm{Pb}$ decreases germination percent, germination index, root/shoot length, tolerance index and dry mass of roots and shoots (Mishra and Choudhari, 1998). High concentrations of $\mathrm{Pb}(1 \mathrm{mM})$ caused 14 to $30 \%$ decreased germination in rice seeds and reduced the growth of seedlings by more than 13 to $45 \%$ (Verma and Dubey, 2003). In Lupinus, $\mathrm{Pb}$ reduced the number of germinating seeds and caused shortening of hypocotyl as well as roots (Wozny et al., 1982).

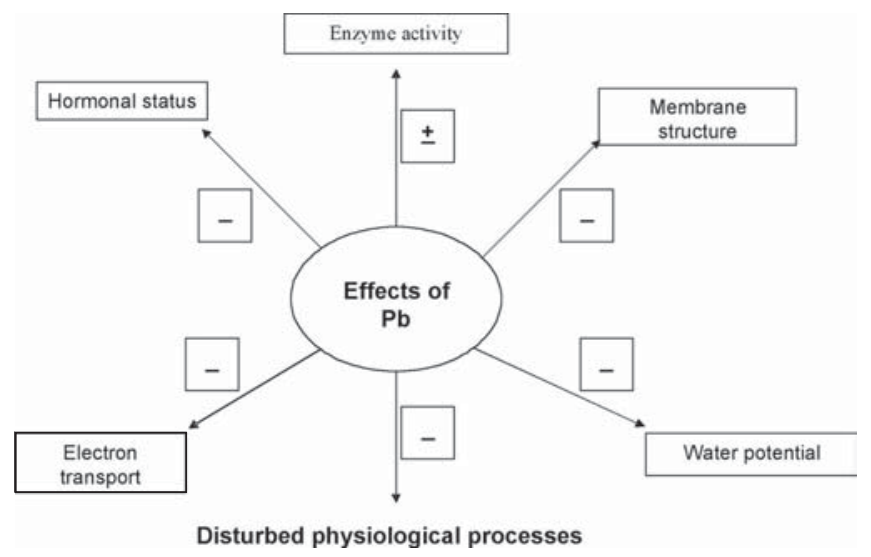

Figure 2. A generalized view of lead toxicity in plants. $\mathrm{Pb}$ phytotoxicity involves decreased water potential, alteration in membrane permeability, decrease in hormonal status and electron transport activities, whereas activities of enzymes are either increased or inhibited. These events ultimately result in overall disturbed physiological processes. '+' and '-' signs indicate positive and negative effects respectively.
Plant roots rapidly respond to absorbed $\mathrm{Pb}$, through a reduction in growth rate and change in branching pattern. Several workers have reported the inhibition of root growth at $10^{-2}$ to $10^{-6} \mathrm{M} \mathrm{Pb}$ concentration or at a soil $\mathrm{Pb}$ content above $10 \mathrm{mg} / \mathrm{kg}$ (Breckle, 1991). At lower concentrations of $\mathrm{Pb}$, development and extension of the main root is affected much more than the lateral roots (Obroucheva et al., 1998). Godbold and Kettner (1991) reported that Picea abies plants when exposed to $\mathrm{Pb}$ at concentrations of 0.1 to $2 \mu \mathrm{M}$ showed increased $\mathrm{Pb}$ content in roots with increasing $\mathrm{Pb}$ supply. A four week exposure of the growing plants to $0.5 \mu \mathrm{M} \mathrm{Pb}$ reduced the growth of primary, secondary and tertiary roots. The initiation of lateral roots appeared to be more sensitive to $\mathrm{Pb}$ than the growth of primary roots. In Zea mays seedlings, Obroucheva et al. (1998) observed strong inhibition of primary root growth and a shorter branching zone with more compact lateral roots occupying a position much closer to the root tip compared with roots grown in the absence of $\mathrm{Pb}$. It appears that the inhibition of root growth under $\mathrm{Pb}$ toxicity is as a result of $\mathrm{Pb}$-induced inhibition of cell division in root tips (Eun et al., 2000). When the effect of different concentrations of $\mathrm{Pb}$ nitrate was studied on root growth, cell division, chromosome morphology and the nucleolus of root tip cells of onion (Allium cepa), a reduction in root growth, mitotic irregularities and chromosome stickiness were observed (Wierzbicka, 1994). The interphase cells possessed micronuclei, irregularly shaped nuclei and nuclei with decomposed nuclear material under $\mathrm{Pb}$ treatment (Wierzbicka, 1994). $\mathrm{Pb}$ treatment perturbs the alignment of microtubules in a concentration dependent manner beginning at $10 \mu \mathrm{M}$ and this may, at least in part, contribute to the inhibition of root growth seen in the presence of $\mathrm{Pb}$ (Yang et al., 2000). Pb destroys microtubules of the mitotic spindle causing characteristic c-mitoses to occur by blocking cells in pro-metaphase. This blocking however is not permanent (Wierzbicka, 1994). Microtubules of different regions of the root meristem and in different stages of the cell cycle show differential susceptibility to lead. These effects do not appear to be a general phenomenon common to toxic metals since $\mathrm{Al}$ and $\mathrm{Cu}$ at a concentration that decreases root growth to a comparable level did not show similar detrimental effects on microtubules (Eun et al., 2000). Based on such observations it is suggested that the damage to microtubules by $\mathrm{Pb}$ is an important component of $\mathrm{Pb}$-induced injury in plants (Eun et al., 2000).

In corn seedlings $\mathrm{Pb}$ toxicity causes leakage of $\mathrm{K}$ ions from root cells (Malkowski et al., 2002). In seedlings treated with $10^{-4}$ to $10^{-3} \mathrm{M} \mathrm{Pb}$, growth of mesocotyl and coleoptyl 
was similarly affected, although the concentration of $\mathrm{Pb}$ was 3 fold higher in the mesocotyl tissues than in the coleoptyl. It is proposed that in corn seedlings depression of shoot growth is not as a consequence of potassium leakage or $\mathrm{Pb}$ accumulation but due to an unknown signal induced in roots, as a response to exposure of $\mathrm{Pb}$ which is transmitted to the shoots (Malkowski et al., 2002). A considerable decrease in dry weights of plant parts is observed under $\mathrm{Pb}$ treatment (Kosobrukhov, 2004). However in certain cases, as in corn seedlings, an apparent increase in dry weight of plant organs was reported which was due to an increase in the synthesis of cell wall polysaccharides resulting from $\mathrm{Pb}$ exposure (Wierzbicka, 1998). $\mathrm{Pb}$ toxicity lowers the protein content of tissues and causes significant alterations in lipid composition (Przymusinski et al., 1991; Stefanov et al., 1995). In $P$. vulgaris and $Z$. mays plants substantial changes were observed in the level of glycolipids, especially monogalactosyl diacylglycerols, which are associated with membrane permeability in chloroplasts (Stefanov et al., 1993). Incubation in presence of $\mathrm{Pb}$ salts invariably results in a decreased level of saturated fatty acids and an increased level of unsaturated fatty acids (18:3) (Stefanov et al., 1995). Synthesis of DNA, RNA and protein were greatly reduced in the embryo axis and endosperms of germinating rice seedlings with increasing concentration of $\mathrm{Pb}$ (Maitra and Mukherji, 1977).

Enzymes activities: Like various heavy metals, $\mathrm{Pb}$ treatment influences the activity behaviours of a wide range of enzymes of different metabolic pathways. Increasing attention has been paid to understand the action of $\mathrm{Pb}$ on plant enzymes. $\mathrm{Pb}$ at a concentration of $10^{-5}$ to $2 \times 10^{-4} \mathrm{M}$ produces about 50 $\%$ inhibition of many enzymes. This concentration is defined as the inactivation constant (Ki). In most, the inhibition exerted by $\mathrm{Pb}$ on enzyme activity results from the interaction of $\mathrm{Pb}$ with enzyme $-\mathrm{SH}$ groups (Levina, 1972). $\mathrm{Pb}$ interacts with free-SH groups that are present in the active site of the enzyme and essential for enzyme activity as well as with - SH groups that are necessary for the stabilization of enzyme tertiary structure. Besides the reaction with - $\mathrm{SH}$ groups, blockage of $-\mathrm{COOH}$ groups with $\mathrm{Pb}$ ions also appears to play a major role in inhibition of enzyme activity under $\mathrm{Pb}$ treatment. $\mathrm{Pb}$ forms a mercaptide with the $-\mathrm{SH}$ group of cysteine and also forms complexes with phosphate groups. Inhibition of metalloenzymes under $\mathrm{Pb}$ treatment appears to be due to displacement of the essential metal by $\mathrm{Pb}$. The inhibition of enzyme activity due to $\mathrm{Pb}$ does not appear to be specific for $\mathrm{Pb}$, as such inhibitions are also evident with other cations having comparable affinities for protein functional groups.
Table 2 presents an overview of the effect of $\mathrm{Pb}$ treatment on the activities of various enzymes reported from different plant species. The key enzyme of chlorophyll biosynthesis, $\delta$-amino laevulinate dehydrogenase, is strongly inhibited by $\mathrm{Pb}$ ions (Prassad and Prassad, 1987). Pb also inhibits the activities of enzymes of the reductive pentose phosphate pathway (Hampp et al., 1973). In leaf homogenates of spinach the activity of ribulose-bis-phosphate carboxylase/ oxygenase was inhibited even at a $\mathrm{Pb}$ nitrate concentration of $5 \mu \mathrm{M}$ (Vallee and Ulmer, 1972). Lactate dehydrogenase showed a similar but a less pronounced decrease in activity. However, the activity of pyruvate kinase was enhanced by $\mathrm{Pb}$ nitrate (Vallee and Ulmer, 1972). $\mathrm{Pb}$ acetate has been shown to considerably decrease the activities of protease and $\alpha$-amylase in rice endosperms after 4 days of germination, whereas RNase and DNase activities are not much affected (Mukherji and Maitra, 1976). A decrease in activity of glutamate dehydrogenase and a low content of nitrate have been observed in leaves of $\mathrm{Pb}$-treated soybean plants whereas no significant change could be observed in malate dehydrogenase activity (Lee et al., 1976). Pb was found to be highly effective in inhibiting ATP synthetase/ATPase (Tu Shu and Brouillette, 1987).

Activities of several enzymes are reported to be enhanced by $\mathrm{Pb}$ treatment. Such apparent enhancement results from changes in enzyme synthesis, immobilization of enzyme inhibitors, or as a result of effector molecules, which are synthesized under $\mathrm{Pb}$ phytotoxicity. Soybean plants grown in culture media containing 20-100 mg.L-1 Pb showed increased activity of acid phosphatase, $\alpha$-amylase and peroxidase in leaves (Lee et al., 1976). Increased activity of hydrolytic enzymes as well as of peroxidase in soybean leaves under $\mathrm{Pb}$ treatment parallels with the senescence of leaves. An increase in the activity of the RNA hydrolyzing enzyme ribonuclease and of protease has been observed in submerged aquatic angiospermic plants growing in presence of $\mathrm{Pb}$ acetate (Jana and Choudhari, 1982).

$\mathrm{As} \mathrm{Pb}$ promotes the formation of reactive oxygen species in plants leading to oxidative stress, an increase in the activity of certain antioxidative enzymes has been observed in $\mathrm{Pb}$-treated plants. Rice plants grown for 20 days in sand cultures containing $0.5 \mathrm{mM}$ and $1 \mathrm{mM} \mathrm{Pb}\left(\mathrm{NO}_{3}\right)_{2}$ showed increased activities of the antioxidative enzymes superoxide dismutase, guaiacol peroxidase, ascorbate peroxidase and glutathione reductase in roots and leaves (Verma and Dubey, 2003). However, activities of the antioxidative metalloenzymes decline when $\mathrm{Pb}$ displaces metals that are an essential part of enzyme. 
Plant species differing in $\mathrm{Pb}$ tolerance show varying behaviour of certain enzymes under $\mathrm{Pb}$ treatment. Igoshina and Kositsin (1990), while studying the effect of $\mathrm{Pb}$ on carboanhydrase activities in the tolerant and sensitive species of melic-grass (Melica nutans), observed that in tolerant melic-grass population, $\mathrm{Pb}$ activated carboanhydrase activity whereas in the sensitive plants the activity of this enzyme remained unaffected.

Photosynthesis: The process of photosynthesis is adversely affected by $\mathrm{Pb}$ toxicity. Plants exposed to $\mathrm{Pb}$ ions show a decline in photosynthetic rate which results from distorted chloroplast ultrastructure, restrained synthesis of chlorophyll, plastoquinone and carotenoids, obstructed electron transport, inhibited activities of Calvin cycle enzymes, as well as deficiency of $\mathrm{CO}_{2}$ as a result of stomatal closure. Ceratophyllum demersum plants when grown in aquatic medium containing $\mathrm{Pb}\left(\mathrm{NO}_{3}\right)_{2}$ showed distinct changes in chloroplast fine structure (Rebechini and Hanzely, 1974). Leaf cells of such plants exhibited a reduction in grana stacks together with a reduction in the amount of stroma in relation to the lamellar system as well as absence of starch grains. $\mathrm{Pb}$ treatment also changes the lipid composition of thylakoid membranes (Stefanov et al., 1995). Effects of $\mathrm{Pb}$ on various components of photosynthesis, mitotic irregularities, respiration, water regime and nutrient uptake are shown in figure 3.

$\mathrm{Pb}$ inhibits chlorophyll synthesis by causing impaired uptake of essential elements such as $\mathrm{Mg}$ and Fe by plants (Burzynski, 1987). It damages the photosynthetic apparatus due to its affinity for protein $\mathrm{N}$ - and S- ligands (Ahmed and Tajmir-Riahi, 1993). An enhancement of chlorophyll degradation occurs in $\mathrm{Pb}$-treated plants due to increased

Table 2. Effect of $\mathrm{Pb}$ on activities of enzymes of different metabolic processes.

\begin{tabular}{|c|c|c|c|c|}
\hline Metabolic processes & Enzymes & Plant species & Effect of $\mathrm{Pb}$ & References \\
\hline Chlorophyll synthesis & $\delta$-Aminolaevulinate & Pennisetum typhoideum & - & Prassad and Prassad 1987 \\
\hline \multirow[t]{2}{*}{$\mathrm{CO}_{2}$ fixation } & Ribulose-1,5 bis phosphate & Avena sativa & - & Moustakas et al. (1994) \\
\hline & $\begin{array}{l}\text { Phosphoenol pyruvate } \\
\text { Carboxylase }\end{array}$ & Zea mays & - & Vojtechova and Leblova (1991) \\
\hline \multirow[t]{2}{*}{ Calvin cycle } & $\begin{array}{l}\text { Glyceraldehyde 3-phosphate } \\
\text { dehydrogenase }\end{array}$ & Spinach oleracea & - & Vallee and Ulmer (1972) \\
\hline & Ribulose 5-phosphate kinase & Spinach oleracea & - & Vallee and Ulmer (1972) \\
\hline Pentose phosphate pathway & $\begin{array}{l}\text { Glucose 6-phosphate } \\
\text { dehydrogenase }\end{array}$ & Spinach oleracea & - & Vallee and Ulmer (1972) \\
\hline \multirow[t]{2}{*}{$\mathrm{N}_{2}$ assimilation } & Nitrate reductase & Cucumis sativus & - & Burzynski (1990) \\
\hline & Glutamine synthetase & Glycine max & - & Lee et al. (1976) \\
\hline \multirow[t]{2}{*}{ Nucleolytic enzymes } & Deoxyribonuclease & Hydrilla verticillata & + & Jana and Choudhary (1982) \\
\hline & Ribonuclease & Hydrilla verticillata & + & Jana and Choudhary (1982) \\
\hline Protein hydrolysis & Protease & Hydrilla verticillata & + & Jana and Choudhary (1982) \\
\hline \multirow[t]{2}{*}{ Phosphohydrolase } & Alkaline phosphatase & Hydrilla verticillata & + & Jana and Choudhary (1982) \\
\hline & Acid Phosphatase & Glycine $\max$ & + & Lee at al. (1976) \\
\hline Sugar metabolism & $\alpha$-amylase & Oryza sativa & - & Mukherji and Maitra (1977) \\
\hline \multirow[t]{2}{*}{ Energy generation } & ATP synthetase & Zea mays & - & Tu Shu and Brouillette (1987) \\
\hline & ATPase & Zea mays & - & Tu Shu and Brouillette (1987) \\
\hline \multirow[t]{6}{*}{ Antioxidative metabolism } & Catalase & Oryza sativa & - & Verma and Dubey (2003) \\
\hline & Guaiacol peroxidase & Glycine $\max$ & + & Lee et al. (1976) \\
\hline & Ascorbate oxidase & Phaseolus aureus & + & Rashid and Mukherjee (1991) \\
\hline & Ascorbate peroxidase & Oryza sativa & + & Verma and Dubey (2003) \\
\hline & Glutathione reductase & Oryza sativa & + & Verma and Dubey (2003) \\
\hline & Superoxide dismutase & Oryza sativa & + & Verma and Dubey (2003) \\
\hline
\end{tabular}

Signs '-' and '+' represent inhibition or increase in enzyme activity, respectively, in Pb treated plants. 


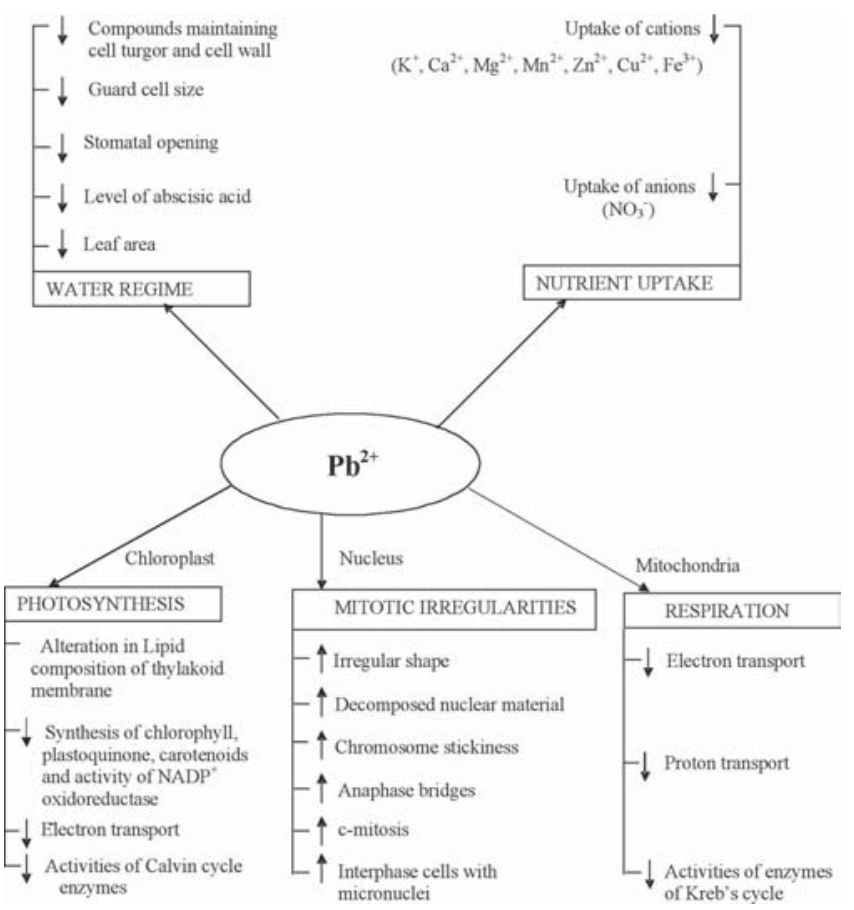

Figure 3. Effect of $\mathrm{Pb}$ on photosynthesis, mitotic irregularities, respiration, water regime and nutrient uptake. ' $\uparrow$ ' and ' $\downarrow$ ' signs represent enhanced and decreased activities respectively.

chlorophyllase activity (Drazkiewicz, 1994). Chlorophyll b is reported to be more affected than chlorophyll $a$ by $\mathrm{Pb}$ treatment (Vodnik et al., 1999). Pb also inhibits electron transport (Rashid et al., 1994). Pb effects have been reported for both donor and acceptor sites of PS II, the cytochrome b/f complex and PS I. It is largely accepted that PS I electron transport is less sensitive to inhibition by Pb than PS II (Mohanty et al., 1989; Sersen et al., 1998).

$\mathrm{Pb}$ also causes strong dissociation of the oxygen evolving extrinsic polypeptide of PS II and displacement of $\mathrm{Ca}, \mathrm{Cl}^{-}$, Mn from the oxygen-evolving complex (Rashid et al., 1991). Ahmed and Tajmir-Riahi (1993) found conformational changes in light-harvesting chlorophyll (LHC II) subunits, following binding with $\mathrm{Pb}$ in vitro. It is proposed that conformational changes induced by $\mathrm{Pb}$ treatment might lead to incomplete assembly followed by degradation (Ahmed and Tajmir-Riahi, 1993).

A strong relationship exists between $\mathrm{Pb}$ application and a decrease in photosynthesis of the whole plant and is believed to result from stomatal closure rather than a direct effect of $\mathrm{Pb}$ on the process of photosynthesis (Bazzaz et al., 1975). According to Kosobrukhov and coworkers (2004), the photosynthetic activity of plant is governed by many factors including stomatal cell size, number of stomata, stomatal conductance, leaf area etc. While studying the effects of $\mathrm{Pb}$ on the development of thylakoid of cucumber and poplar plants Savari and coworkers (2002) observed increased chlorophyll content either in the PS II core or LHC II at low concentrations of $\mathrm{Pb}$ treatment, whereas a strong decrease in chlorophyll level of seedlings was seen at the $50 \mathrm{mM} \mathrm{Pb}$. At $50 \mathrm{mM} \mathrm{Pb}$ treatment level the concentration of $\mathrm{Pb}$ inside the leaf might have been high enough to directly inhibit chlorophyll synthesis (Sengar and Pandey, 1996).

Respiration and ATP content: $\mathrm{Pb}$ exerts a significant effect on respiration and ATP content of photosynthetic organisms. In vitro application of $\mathrm{Pb}$ to mitochondrial preparations from plant cells revealed a decrease in respiration rate with increasing $\mathrm{Pb}$ concentrations (Reese and Roberts, 1985). Using isolated chloroplasts and mitochondria in different plant species it has been shown that $\mathrm{Pb}$ affects the flow of electrons via the electron transport system (Miles et al., 1972; Bazzaz and Govindjee, 1974). The inhibitory effect of $\mathrm{Pb}$ at higher concentrations appears to be due to uncoupling of oxidative phosphorylation (Miller et al., 1973). At lower concentrations, however, a stimulation of respiration is observed in whole plants (Lee et al., 1976), detached leaves (Lemoreaux and Chaney, 1978), isolated protoplasts (Parys et al., 1998) and mitochondria (Koeppe and Miller, 1970). The exposure of detached leaves of $\mathrm{C}_{3}$ plants (pea, barley) and $\mathrm{C}_{4}$ plants (maize) to $5 \mathrm{mM} \mathrm{Pb}\left(\mathrm{NO}_{3}\right)_{2}$ for $24 \mathrm{~h}$ caused stimulation of the respiratory rate by $20-50 \%$ (Romanowska et al., 2002). Mitochondria isolated from $\mathrm{Pb}$-treated pea leaves oxidized substrates (glycine, succinate, malate) at higher rates than mitochondria from control leaves (Romanowska et al., 2002). The respiratory control and the ADP/O were not affected by $\mathrm{Pb}$ treatment. $\mathrm{Pb}$ caused an increase in ATP content as well as an increase in the ATP/ADP ratio in pea and maize leaves (Romanowska et al., 2002). Rapid fractionation of barley protoplasts incubated at low and high $\mathrm{CO}_{2}$ conditions, indicated that the increased ATP/ADP ratio in Pb-treated leaves resulted mainly from the production of mitochondrial ATP. The activity of $\mathrm{NAD}^{+}$-malate dehydrogenase in protoplasts of barley leaves treated with $\mathrm{Pb}$ was 3-fold higher than the protoplasts from control leaves (Romanowska et al., 2002). The activities of photorespiratory enzymes NADH-hydroxypyruvate reductase and glycolate oxidase as well as of NAD-malic enzyme were however, not affected by $\mathrm{Pb}$ treatment (Romanowska et al., 2002). The mechanism underlying the stimulation of respiration by $\mathrm{Pb}$ is not clear. According to Ernst (1980) the higher respiration rate observed under $\mathrm{Pb}$ 
toxicity could be due to an increased demand for ATP production through oxidative phosphorylation.

The key enzyme of $\mathrm{CO}_{2}$ assimilation in $\mathrm{C}_{3}$ plants ribulose-bisphosphate carboxylase, is sensitive to $\mathrm{Pb}$ whereas the oxygenase activity remains relatively unaffected (van Assche and Clijsters, 1990). Therefore, it is quite possible that after $\mathrm{Pb}$ treatment when photosynthesis is significantly reduced, photorespiration could continue at a similar rate. This would increase the relative rate of photorespiration to photosynthesis. The inhibition of photosynthesis observed after $\mathrm{Pb}$ treatment leads to decreased utilization of ATP for $\mathrm{CO}_{2}$ fixation. In leaf extracts of $\mathrm{Pb}$-treated plants higher in ATP/ADP ratios have been observed compared to untreated plants (van Assche and Clijsters, 1990). Leaves of Pb-treated plants show increased respiration, which appears to be a result of oxidation of excess photosynthetic reducing equivalents, which are produced under conditions of limited $\mathrm{CO}_{2}$ fixation (Poskuta et al., 1996).

At higher concentrations of $\mathrm{Pb}$, inhibition of respiration is observed. Respiration of corn root tips decreased by 10-17 $\%$ after $1 \mathrm{~h}$ treatment with $20 \mathrm{mM} \mathrm{Pb}$ and by $28-40 \%$ after $3 \mathrm{~h}$ treatment (Koeppe, 1977). $\mathrm{Pb}$ is regarded as one of the most potent metal ions for the inhibition of chloroplastic ATP synthetase/ATPase activity and for the destruction of the membranes (Tu Shu and Brouillette, 1987). Although the sensitivity of photophosphorylation to heavy metal ions is well documented, there is no general agreement regarding their site of action nor on the underlying mechanism. Some experiments suggest that different mechanisms exist for the action of heavy metal ions on chloroplastic ATPase activity when these metal ions are applied under in vivo and in vitro conditions.

Nutrient uptake: High concentrations of $\mathrm{Pb}$ the in soil environment causes imbalance of mineral nutrients in growing plants. Many of the observed actions of $\mathrm{Pb}$ appear to be indirect as a result of mineral imbalance within the tissues. Significant changes in nutrient contents as well as in internal ratios of nutrients occur in plants under $\mathrm{Pb}$ toxicity (KabataPendias and Pendias, 1992). In most cases Pb blocks the entry of cations $\left(\mathrm{K}^{+}, \mathrm{Ca}, \mathrm{Mg}, \mathrm{Mn}, \mathrm{Zn}, \mathrm{Cu}, \mathrm{Fe}^{3+}\right)$ and anions $\left(\mathrm{NO}_{3}{ }^{-}\right)$ in the root system (Figure 3). Two mechanisms for decreased uptake of micro and macronutrients under $\mathrm{Pb}$ toxicity have been suggested. The first mechanism, termed physical, relies on the size of metal ion radii, whereas the second mechanism, which is a chemical one, relies on the metal-induced disorder in the the cell metabolism leading to changes in membrane enzyme activities and membrane structure. The efflux of $\mathrm{K}^{+}$ from roots, apparently due to the extreme sensitivity of $\mathrm{K}^{+}$ATPase and - $\mathrm{SH}$ groups of cell membrane proteins to $\mathrm{Pb}$, is an example of the second type of mechanism.

$\mathrm{Pb}$ physically blocks the access of many ions from absorption sites of the roots (Godbold and Kettner, 1991). Although $\mathrm{Pb}$ levels in root tips and the basal root may appear to be similar, $\mathrm{Pb}$ alters the levels of mineral elements in the roots. In root tips the levels of $\mathrm{Ca}, \mathrm{Fe}, \mathrm{Zn}$ decrease after exposure to $\mathrm{Pb}$. In root tips of Norway spruce $40 \%$ of the Ca taken up was used in root tips growth. The inhibition of root growth after exposure to $\mathrm{Pb}$ may be due to a decrease in $\mathrm{Ca}$ in the root tips, leading to a decrease in cell division or cell elongation (Haussling et al., 1988). In Norway spruce needles, the level of $\mathrm{Ca}$ and $\mathrm{Mn}$ decrease with $\mathrm{Pb}$ treatment, which could be a result of a decrease in number of root tips and sites for apoplastic solute flux through the endodermis. In Picea abies $\mathrm{Pb}$ treatment lowered the Mn level of the needles (Sieghardt, 1988). In Cucumis sativus seedlings $\mathrm{Pb}$ decreased the uptake of $\mathrm{K}, \mathrm{Ca}, \mathrm{Mg}, \mathrm{Fe}$ and $\mathrm{NO}_{3}{ }^{-}$and in Zea mays the uptake of $\mathrm{Ca}, \mathrm{Mg}, \mathrm{K}$ and $\mathrm{P}$ (Walker et al., 1997). $\mathrm{Pb}$ influences the overall distribution of nutritional elements within the different organs of the plant. The overall distribution ratio of $\mathrm{Mn}$ and $\mathrm{S}$ changed in favour of root over shoot under $\mathrm{Pb}$ toxicity, which may represent retention of these ions in root. Phosphorus content was found to be negatively correlated with soil $\mathrm{Pb}$ (Paivoke, 2002). Root nitrogen content is significantly reduced under $\mathrm{Pb}$ toxicity. Nitrate uptake declines in plants under exposure to $\mathrm{Pb}$ with a concomitant lowering of nitrate reductase activity and disturbed nitrogen metabolism (Burzynski and Gabrowski, 1984). The decline in nitrate uptake due to $\mathrm{Pb}$ may be as a result of moisture stress created by $\mathrm{Pb}$ (Burzynski and Gabrowski, 1984). In certain plant species like Pisum sativum, elevated nitrogen content is observed in roots at a $\mathrm{Pb}$ treatment level of $2 \mathrm{mM}$ $\mathrm{kg}^{-1}$ soil which probably occurs due to inhibitory effects of $\mathrm{Pb}$ on NR activity (Paivoke, 2002).

Water status: A decline in transpiration rate and water content in tissues occurs in plants growing under $\mathrm{Pb}$ exposure. Various mechanisms have been suggested for the $\mathrm{Pb}$-induced decline in transpiration rate and water content. $\mathrm{Pb}$ treatment causes growth retardation, which results in a reduced leaf area, the major transpiring organ (Iqbal and Moshtaq, 1987). Guard cells are generally smaller in size in plants treated with $\mathrm{Pb}$. Pb lowers the level of compounds that are associated with maintaining cell turgor and cell wall plasticity and thus low- 
ers the water potential within the cell. Metal ions including $\mathrm{Pb}$ increase the content of $\mathrm{ABA}$ and induce stomatal closure (Figure 3). Disordered respiration and oxidative phosphorylation observed under $\mathrm{Pb}$ toxicity may also cause disarray in the plant water regime. Experiments using epidermal peels floating on $\mathrm{Pb}$ solutions have shown that $\mathrm{Pb}$ induces stomatal closure (Bazzaz et al., 1974). Experiments using excised leaves have indicated that metals increase stomatal resistance not only when directly applied to guard or epidermal cells but also when they reach the cells via xylem (Bazzaz et al., 1974). A unified hypothesis regarding $\mathrm{Pb}$-induced stomatal closure indicates that such effect is due to the inhibition of an energy system or due to alterations of $\mathrm{K}^{+}$fluxes through membranes (Bazzaz et al., 1974).

Oxidative metabolism: One of the phytotoxic effects of $\mathrm{Pb}$ appears to be induction of oxidative stress in growing plant parts due to enhanced production of reactive oxygen species (ROS) resulting in an unbalanced cellular redox status. A number of different ROS, including the superoxide anion $\left(\mathrm{O}_{2} \cdot{ }^{-}\right)$, singlet oxygen $\left({ }^{1} \mathrm{O}_{2}\right)$, hydrogen peroxide $\left(\mathrm{H}_{2} \mathrm{O}_{2}\right)$ and the hydroxyl radical $(\mathrm{OH})$ are produced during normal oxidative metabolism in aerobic organisms, but these ROS can pose a severe threat when produced in larger amounts. Although some of the ROS may function as important signaling molecules altering gene expression and modulating activity of specific defense proteins, all ROS can be extremely harmful to organisms at high concentrations.

$\mathrm{Pb}$ induces production of ROS within plants and such production depends on the intensity of the stress, repeated stress periods, species and plant age (Asada, 1994; Chaitnya and Naithani, 1999; Verma and Dubey, 2003). Lipid peroxidation, which is regarded as indicator of oxidative damage, involves oxidative degradation of polyunsaturated fatty acyl residues of membranes (Girotti, 1990). $\mathrm{Pb}$ ions induce lipid peroxidation, decrease the level of saturated fatty acids and increase the content of unsaturated fatty acids of membrane in several plant species (Halliwell and Gutteridge, 1999). Although the ROS generating processes are slow under normal conditions, $\mathrm{Pb}$ accelerates them (Verma and Dubey, 2003). When rice (Oryza sativa) seedlings were grown in sand culture under 500 and $1000 \mu \mathrm{M} \mathrm{Pb}\left(\mathrm{NO}_{3}\right)_{2}$ in the medium, during a growth period of 5-20 days about 21 to $177 \%$ increase in the level of lipid peroxides was observed, indicating that $\mathrm{Pb}$ induces oxidative stress in these plants (Verma and Dubey, 2003).
A wide range of protective mechanisms exist in plants that serve to remove ROS before they can damage sensitive parts of the cellular machinery. These mechanisms can be conveniently divided in two groups, that is, non-enzymic antioxidants such as glutathione, ascorbate, tocopherols, carotenoids, etc. and the enzymic antioxidants like catalase, peroxidases, superoxide dismutases (SOD) as well as enzymes of ascorbate-glutathione cycle such as ascorbate peroxidase (APX), monodehydroascorbate reductase (MDHAR), dehydroascorbate reductase (DHAR) and glutathione reductase (GR) (Verma and Dubey, 2003).

$\mathrm{Pb}$ is not a oxido-reducing metal like iron, therefore the oxidative stress induced by $\mathrm{Pb}$ in plants appears to be an indirect effect of $\mathrm{Pb}$ toxicity leading to production of ROS, enhancing pro-oxidant status of cell by reducing the pool of reduced glutathione (GSH), activating calcium-dependent systems and affecting iron-mediated processes (Pinto et al., 2003). Figure 4 shows the sequence of events leading to production of ROS by $\mathrm{Pb}$ during membrane-linked electron transport and the role of antioxidative enzymes in scavenging ROS and maintaining the level of antioxidants ascorbate (AsA) and glutathione (GSH). Among the antioxidative enzymes, catalase decomposes $\mathrm{H}_{2} \mathrm{O}_{2}$ to water and molecular oxygen. A decline in the activity of catalase has been observed in Pb-stressed plants (Verma and Dubey, 2003). Such

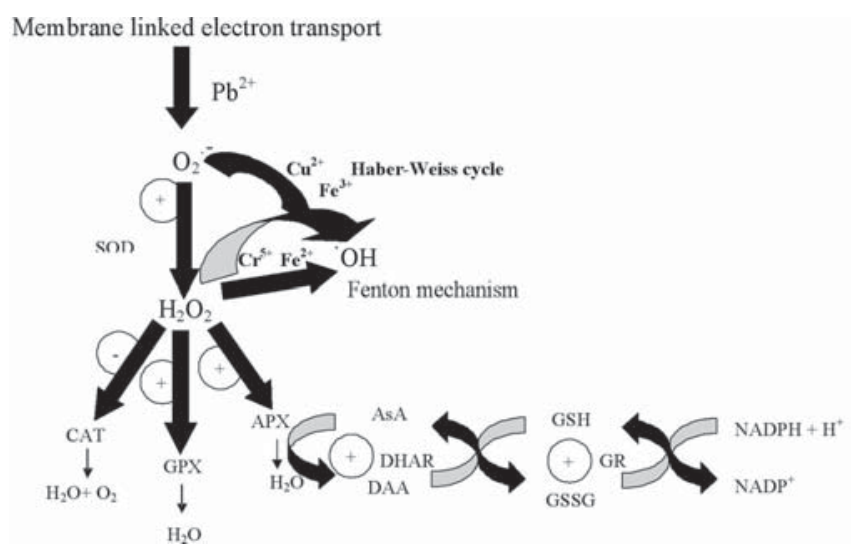

Figure 4. Effect of $\mathrm{Pb}$ on generation of reactive oxygen species and activities of antioxidative enzymes. $\mathrm{Pb}$ induces increased formation of reactive oxygen species $\left(\mathrm{O}_{2}-\mathrm{H}_{2} \mathrm{O}_{2}, \mathrm{OH}\right)$, increases the activities of antioxidative enzymes superoxide dismutase (SOD), guaiacol peroxidase (GPX), ascorbate peroxidase (APX), dehydroascorbate reductase (DHAR) and NADPH dependent glutathione reductase (GR) but decreases the activity of catalase (CAT). The compounds ascorbic acid (AsA) and glutathione (GSH) are important non-enzymic antioxidants within the cell. Their oxidized forms are dehydroascorbic acid (DHA) and GSSG. HaberWeiss cycle and Fenton mechanism generate hydroxyl radical ('OH) from superoxide anion $\left(\mathrm{O}_{2} \cdot{ }^{-}\right)$and $\mathrm{H}_{2} \mathrm{O}_{2}$. The signs ' + ' and '-' denote induction or inhibition due to $\mathrm{Pb}$, respectively. 
a decrease appears to be due to a decline in enzyme synthesis or a change in the assembly of enzyme subunits (Hertwig, 1992). Verma and Dubey (2003) observed decreased intensity of two isozymic forms of catalase in shoots of $\mathrm{Pb}$-stressed seedlings, consistent with decreased activity of the enzyme under $\mathrm{Pb}$ treatment. These isoforms are under the control of different genes (Frugoli et al., 1996). Pb has been reported to induce peroxidase activity in soybean, rice seedlings etc. (Lee et al., 1976; Verma and Dubey, 2003). The role of peroxidase as a stress enzyme (Gaspar, 1982) in plants has been widely accepted (Subhashini and Reddy, 1990). Increased peroxidase activity with $\mathrm{Pb}$ treatment can be correlated with the release of peroxidase localized in the cell walls (Gaspar, 1982). Increased activity of the superoxide scavenging enzyme has been reported in Lupenus lutius and O. sativa plants (Przymusinski et al., 1995; Verma and Dubey, 2003). The increase in the activity of SOD in response to $\mathrm{Pb}$ appears to be due to de novo synthesis of enzymatic protein (Lozano et al., 1996). Pb-stressed rice seedlings also show increased activities of APX and GR (Verma and Dubey, 2003). Though APX is considered a key enzyme of the antioxidative defense mechanism (Sharma and Dubey, 2004) which directly determines the cellular concentration of $\mathrm{O}_{2}{ }^{-}$and $\mathrm{H}_{2} \mathrm{O}_{2}$, the two enzymes SOD and GR appear to play a pivotal role in combating $\mathrm{Pb}$-induced oxidative injury in rice plants (Verma and Dubey, 2003). Increased GR activity under $\mathrm{Pb}$ toxicity helps in recycling oxidized glutathione to reduced glutathione to maintain the ratio of oxidized glutathione to reduced glutathione (GSH/GSSG) and the total glutathione pool (Foyer et al., 1997). The increase in the activity of GR under stress has been attributed to de novo synthesis of the enzyme protein (Baisak et al., 1994).

Lead tolerance in plants: The two basic strategies of metal uptake related to tolerance in plants, as suggested by Baker (1981), involve (i) the 'excluder' strategy in which the concentration of heavy metals is maintained at a constant low level until critical soil concentration is reached when toxicity ensues and unrestricted metal transport results and (ii) the 'accumulator' strategy in which metals are actively concentrated within the plant tissues over the full range of soil concentration implying a highly specialized physiology. Berry (1986) also suggested three basic strategies of response: avoidance, detoxification and biochemical tolerance each of which affects tissue metal concentrations in different ways. Figure 5 describes various responses of cells, when plants are exposed to $\mathrm{Pb}$. These responses include exclusion, detoxification mechanisms and non-specific defense systems.
It was shown by Ye and coworkers (1997) that Typha latifolia can colonize in both uncontaminated and metal-polluted areas and that the concentrations of $\mathrm{Pb}$ in the leaves are maintained at low levels. Similar results have been reported for this species by other authors. Collectively these observations indicate that $T$. latifolia tolerates $\mathrm{Pb}$ and that this tolerance ability depends mainly on metal exclusion ability. Metal tolerance and metal exclusion ability of this species appears to be related to its oxygen transport capability and radial oxygen loss from the roots resulting in a greater ability to modify the rhizosphere and immobilize metals in the rhizosphere

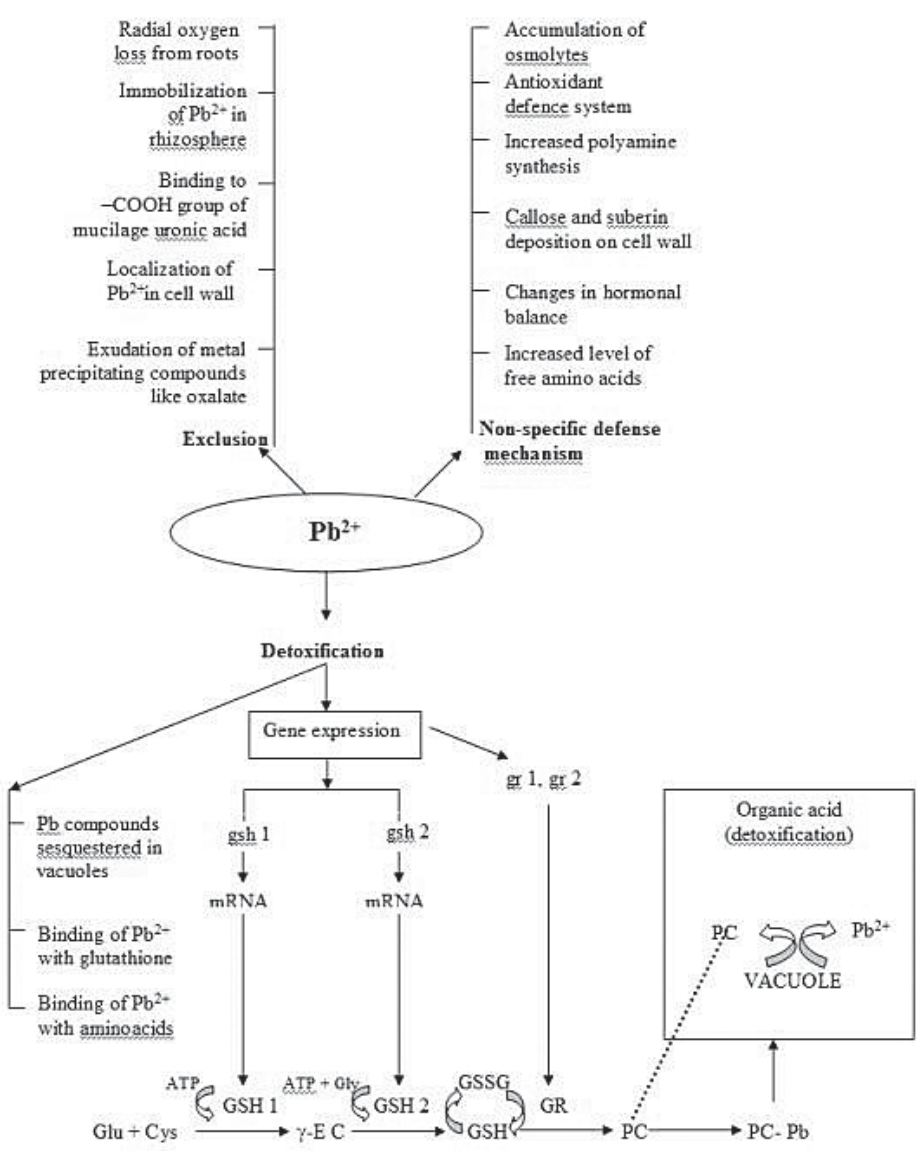

Figure 5. Response of plant cell to toxic levels of $\mathrm{Pb}$. Exclusion capacity of plants is related to radial oxygen loss from root, efficiency to immobilize metals in rhizosphere, localization in cell wall, binding to $-\mathrm{COOH}$ groups of mucilage uronic acid and its precipitation by oxalate, whereas detoxification mechanisms include sequestratio $\mathrm{n}$ of $\mathrm{Pb}$ in the vacuoles by the formation of complexes, Binding of $\mathrm{Pb}$ to glutathione (GSH), amino acids (AA), phytochelatins (PCs). The synthesis of PCs accompanies with decrease in cell glutathione pool and increase in the activities of glytamyl cysteine synthetase (GSH 1), glutathione synthetase (GSH 2) as well as glutathione reductase (GR). The elevated activities of GSH 1, GSH 2 and GR is correlated with enhanced expression of corresponding genes gsh 1 , gsh 2 , gr 1 and gr 2 . Nonspecific defense mechanisms induced due to $\mathrm{Pb}$ include accumulation of osmolytes, antioxidants, callose and suberin, amino acids and changes in hormonal balance. 
(Ye et al., 1997). Rice roots have been reported to synthesize oxalate via the oxidation of glycolate to glyoxylate and then oxidation of glyoxylate to oxalate. Tolerant rice varities upregulate the synthesis and secretion of oxalate, a compound that precipitates $\mathrm{Pb}$ thereby reducing its uptake by root (Yang et al., 2000). Binding of $\mathrm{Pb}$ to the carboxy groups of mucilage uronic acids also restricts uptake of $\mathrm{Pb}$ into the root (Morel et al., 1986).

Strong binding of $\mathrm{Pb}$ to the carboxyl groups of carbohydrate in cell walls leads to its diminished transport via apoplast (Rudakova et al., 1988). An electron microscopic study of root tips from tolerant plants reveals the presence of $\mathrm{Pb}$ in the cell wall as well as the cytoplasm. It is suggested that the tolerance mechanism in Anthoxanthum odoratum plants is associated with its capacity to restrict the localization of $\mathrm{Pb}$ to the cell walls (Qureshi et al., 1986). Within the cell the major part of $\mathrm{Pb}$ is sequestered in the vacuole in the form of complexes. This may represent another mechanism of $\mathrm{Pb}$ detoxification in plants. Pinocytosis is observed in leaf cells of many plants treated with $\mathrm{Pb}$ salt solution. Through pinocytotic vesicles, $\mathrm{Pb}$ particles could be discharged into the vacuole (Wierzbica and Antosiewicz, 1993). Accumulation of excess total amino acid in response to $\mathrm{Pb}$ can be regarded as an important adaptive response of plants to avoid $\mathrm{Pb}$ toxicity. Several workers have emphasized the importance of the synthesis of metal chelating compounds such as amino acids like proline to avoid heavy metal toxicity (Alia and Saradhi, 1991).

Plants exposed to $\mathrm{Pb}$ and certain other heavy metal pollutants like $\mathrm{Cd}, \mathrm{Zn}, \mathrm{Cu}, \mathrm{Hg}$ synthesize cysteine-rich low molecular weight polypeptides called phytochelatins (Cobbett, 2000). Phytochelatins (PCs) form a family of structures with increasing repetitions of the $\gamma$-Glu-Cys dipeptide followed by a terminal Gly; ( $\gamma$-Glu-Cys) $)_{n}$-Gly, where $\mathrm{n}$ has been reported to be high as 11, but is generally in the range of 2 to 5 (Zenk, 1996). Among the common metal pollutants, $\mathrm{Cd}$ and $\mathrm{Pb}$ are inducers of phytochelatin synthesis and the binding of these metals with PCs has been demonstrated in many plant species (Grill et al., 1987). Binding capacity of phytochelatins to different metals differs. It has been shown that $\mathrm{Pb}$ compounds bind less strongly to $\mathrm{PCs}$ than $\mathrm{Cd}$, due to larger ion radius $(\mathrm{Pb}$, octahedral) and high coordination number $(\mathrm{Pb}$, 6-8). Induction of PC synthesis was shown in cell cultures of Rauwolfia serpentina when $1 \mathrm{mM} \mathrm{Pb}$ was added to the medium. Such synthesis was accompanied by a decrease in the cell glutathione pool (Grill et al., 1987). It is believed that PCs are synthesized from glutathione and such synthesis is due to transpeptidation of $\gamma$-glutamyl cysteinyl dipeptides from glutathione by the action of a constitutively present enzyme, PC synthase (Chen et al., 1997). Phytochelatin binds to $\mathrm{Pb}$ ions leading to sequestration of $\mathrm{Pb}$ ions in plants and thus serve as an important component of the detoxification mechanism in plants.

Several non-specific defense systems are also activated when plants are exposed to $\mathrm{Pb}$. These include synthesis of osmolytes (like proline) and polyamines (putrescine), changes in the chemical composition of the cell wall (callose and suberin deposition), and changes in hormonal balance (primarily that of ethylene and ABA) (Seregin and Ivanov, 2001). There are different opinions regarding mechanisms by which osmolytes (proline) alleviate metal toxicity effects within the cell. It has been shown that free proline acts as an osmoprotectant (Paleg et al., 1984), protein stabilizer (Sharma and Dubey, 2004), metal chelator (Farago and Mullen, 1979), inhibitor of lipid peroxidation (Mehta and Gaur, 1999), free radical scavenger (Alia et al., 2001), etc.

Remediation of lead contaminated soils: The remediation of $\mathrm{Pb}$-contaminated soils represents a significant challenge to many industries and government agencies. To date $\mathrm{Pb}-\mathrm{con}-$ taminated sites have been remediated through a relatively narrow range of engineering based technologies (Salt et al., 1995). Heavily contaminated soils have primarily been excavated, stabilized with cement and then placed in secured landfills. This process is expensive and requires additional site restoration.

During recent years the concept of using plants to remediate heavy metal contaminated sites (called phytoremediation) has received greater attention (Raskin et al., 1994; Vassil et al., 1998; Jarvis and Leung, 2002). Phytoremediation may involve either phytostabilization or phytoextraction. Phytostabilization reduces the intrinsic hazards posed by the contaminant without removing it from the site by reducing the bioavailability in the soil, whereas phytoextraction involves the use of plants to remove the contaminant from contaminated soils. The concept of using plants to accumulate metal for subsequent processing is both technically and economically attractive.

For practical reasons, the shoot $\mathrm{Pb}$ concentration is the most important physiological parameter for evaluating $\mathrm{Pb}$ phytoextraction potential of plants (Huang and Cunningham, 1996). It has been shown that $\mathrm{Pb}$ accumulation in roots is significantly higher than in shoots, possibly because of the low $\mathrm{Pb}$ translocation from roots to shoots (Cunningham et 
al., 1995; Verma and Dubey, 2003). Plant species with higher shoot/root $\mathrm{Pb}$ concentrations are more efficient in $\mathrm{Pb}$ translocation. Thlaspi rotundifolium plants have been reported to accumulate 130-8200 mg Pb. $\mathrm{kg}^{-1}$ shoot dry weight (Reeves and Brooks, 1983). Because of its slow growth rate and small biomass however, this species is not suited for phytoextraction of $\mathrm{Pb}$ from contaminated soils. Some cultivars of Brassica juncea have been shown to accumulate as high as $1.5 \% \mathrm{~Pb}$ in the shoot when grown in nutrient solution containing $760 \mu \mathrm{M} \mathrm{Pb}$ (Kumar et al., 1995). It was reported by Huang and Cunningham (1996) that the $\mathrm{Pb}$ concentration in the shoot of corn was significantly higher than that of the best $\mathrm{Pb}$-accumulating Brassica juncea cultivars when the plants were grown on a $\mathrm{Pb}$ contaminated soil.

Results from chelation experiments indicate that $\mathrm{Pb}$ concentration in the shoot can be increased dramatically when the soil $\mathrm{Pb}$ concentration is increased by adding a synthetic chelate to the contaminated soil. The synthetic chelate EDTA forms a soluble complex with many metals, including $\mathrm{Pb}$ (Kroschwitz, 1995) and can solubilize Pb from soil particles (Vassil et al., 1998). Application of EDTA to $\mathrm{Pb}$-contaminated soils has been shown to induce the uptake of $\mathrm{Pb}$ by plants causing $\mathrm{Pb}$ to accumulate more than $1 \%$ $(\mathrm{w} / \mathrm{w})$ of the shoot dry biomass (Huang and Cunningham, 1996; Huang et al., 1997). Large $\mathrm{Pb}$ particles cannot easily cross the casparian strip due to their size and charge characteristics but once they form a complex with chelators such as EDTA, their solubility increases, the particle size decreases and they become partially 'invisible' to those processes that would normally prevent their unrestricted movement such as precipitation with phosphates and carbonates, or binding to the cell wall through mechanisms such as cation exchange (Jarvis and Leung, 2002). The mechanism by which solutes that have moved symplastically from root epidermal cells to the parenchyma cells and on to the vascular cylinder, enter the vessels or tracheids of the xylem is postulated to be some type of highly selective active-carrier transport, as opposed to facilitated diffusion (Raven et al., 1999). Although it is certain that this mechanism does not involve transport of lead, and that the movement of charged $\mathrm{Pb}$ particles through this route would be impeded to some extent, it is likely that a $\mathrm{Pb}$ chelate complex could pass through this route more successfully. It is important to point out that the addition of chelates to the soil has to be done in a carefully controlled manner so as not to mobilize $\mathrm{Pb}$ into ground water or otherwise promote its off-site migration (Huang and Cunningham, 1996).
Another promising clean-up technology appears to be rhizofiltration, which involves use of plant roots to remove contaminants such as heavy metals from contaminated water (Dushenkov et al., 1995). A high level of $\mathrm{Pb}$ deposition is seen in corn root tips as revealed by histochemical and electron microscopy studies. When the seedlings are incubated in a medium containing $0.66 \mathrm{mM} \mathrm{Pb}$ for 19 days (Tung and Temple, 1996), a strong deposition of $\mathrm{Pb}$ occurs on the surface as well as in internal tissues within the first $2 \mathrm{~mm}$ of tap root and secondary root branches in the seedlings (Tung and Temple, 1996). Malkowski and coworkers (2002) also showed that corn plants treated with $10^{-3} \mathrm{M} \mathrm{Pb}$ accumulated $138,430 \mathrm{mg}$ of $\mathrm{Pb}$ per $\mathrm{kg}$ of dry weight in root tips compared to $26,833 \mathrm{mg}$ in the root basal part. Since the first $8 \mathrm{~mm}$ of the apical root accounts for approximately $50 \%$ of the $\mathrm{Pb}$ accumulated by the entire root system (Malkowski et al., 2002), it appears that the plant with a more branched root system will take up more $\mathrm{Pb}$ and other heavy metals compared to plants with longer and less branched root systems. Though phytoremediation and rhizofiltration technologies are still in developmental stages, for the future these technologies appear to have great potential for the clean-up of soils contaminated with $\mathrm{Pb}$ and other heavy metals.

Conclusion: $\mathrm{Pb}$ has gained considerable attention as a potent heavy metal pollutant due to the growing anthropogenic pressure on the environment. $\mathrm{Pb}$ contaminated soils show a sharp decline in crop productivity. $\mathrm{Pb}$ is taken up by plants mainly through the root system and partly, in minor amounts through the leaves. Inside the plants $\mathrm{Pb}$ accumulates primarily in the root but a part of it is translocated to the aerial portions. Soil $\mathrm{pH}$, soil particle size, cation exchange capacity as well as plant factors such as root surface area, root exudation and mycorrhizal transpiration rate affect the availability and uptake of lead. Limited translocation of $\mathrm{Pb}$ occurs from root to other organs due to the barrier function of the root endodermis. At lethal concentrations this barrier is broken and the flux of $\mathrm{Pb}$ enters the vascular tissues. $\mathrm{Pb}$ deposits of various size are present mainly in the intercellular spaces, cell walls and vacuoles. Small deposits of this metal are also seen in the endoplasmic reticulum, dictyosome and dictyosome derived vesicles.

After entering the cell, $\mathrm{Pb}$ inhibits activities of many enzymes, upsets mineral nutrition and water balance, changes the hormonal status and affects membrane structure and its permeability. Visual non-specific symptoms of $\mathrm{Pb}$ toxicity are stunted growth, chlorosis and blackening of the root sys- 
tem. In most cases inhibition of enzyme activities due to $\mathrm{Pb}$ results from the interaction of the metal with enzyme $-\mathrm{SH}$ groups. The activities of metalloenzymes may decline due to displacement of an essential metal by $\mathrm{Pb}$ from enzyme active sites.

$\mathrm{Pb}$ decreases photosynthetic rate by distorting chloroplast ultrastructure, diminishing chlorophyll synthesis, obstructing electron transport and inhibiting activities of Calvin cycle enzymes. At low concentrations $\mathrm{Pb}$ stimulates respiration and increases ATP content whereas higher concentrations are inhibitory to respiration and decrease ATP. Pb causes the imbalance of the minerals $\mathrm{K}, \mathrm{Ca}, \mathrm{Mg}, \mathrm{Mn}, \mathrm{Zn}, \mathrm{Cu}, \mathrm{Fe}$ within the tissues by physically blocking the access of these ions to the absorption sites of the roots.

$\mathrm{Pb}$ exclusion capacity of plants is related to oxygen transport ability, radial oxygen loss from the root, efficiency to immobilize $\mathrm{Pb}$ in the rhizosphere, binding capacity to $-\mathrm{COOH}$ groups of mucilage uronic acid, its precipitation by oxalate, etc. Mechanisms of $\mathrm{Pb}$ detoxification include sequestration of $\mathrm{Pb}$ in the vacuole by the formation of complexes, binding of $\mathrm{Pb}$ by phytochelatins, glutathione and amino acids. Biochemical tolerance to $\mathrm{Pb}$ is related to the capacity of the plants to restrict $\mathrm{Pb}$ to the cell walls, synthesis of osmolytes and activation of the antioxidant defense system. Further studies are needed to specify the parameters associated with $\mathrm{Pb}$ exclusion and $\mathrm{Pb}$ detoxification capacity of plants as well as those biochemical parameters associated with tolerance to $\mathrm{Pb}$ in plants. Such studies will enlighten the mechanism of the genetic and biochemical basis of $\mathrm{Pb}$ tolerance in crops and based on biotechnological tools it should be possible to produce plants with enhanced $\mathrm{Pb}$ tolerance. Emerging clean-up technologies for remediation of $\mathrm{Pb}$ such as phytoextraction and rhizofiltration have the potential to provide environmentally sound and economically viable remedies for the cleaning of $\mathrm{Pb}$-contaminated soils.

\section{REFERENCES}

Ahmed A, Tajmir-Riahi HA (1993) Interaction of toxic metal ions $\mathrm{Cd}^{2+}, \mathrm{Hg}^{2+}$ and $\mathrm{Pb}$ with light-harvesting proteins of chloroplast thylakoid membranes. An FTIR spectroscopic study. J. Inorg. Biochem. 50:235-243.

Alia, Mohanty P, Matysik J (2001) Effect of proline on the production of singlet oxygen. Amino Acids 21:195-200.

Alia, Saradhi PP (1991) Proline accumulation under heavy metal stress. J. Plant Physiol. 138:554-558.

Angelone M, Bini C (1992) Trace elements concentrations in soils and plants of western Europe. In: Adriano DC (ed), Biogeochemistry of Trace Metals, pp.19-60. Lewis Publishers, Boca Raton, London.
Antosiewicz DM (1992) Adaptation of plants to an environment polluted with heavy metals. Acta Soc. Bot. Polon. 61:281-299.

Asada K (1994) Production and action of active oxygen species in photosynthetic tissues. In: Foyer C, Mullineaux PM (eds), Causes of Photooxidative Stress and Amelioration of Defense Systems in Plants, pp. 77-100. CRC Press, Boca Raton, London.

Baisak R, Rana D, Acharya P, Kar M (1994) Alterations in the activities of active oxygen scavenging enzymes of wheat leaves subjected to water stress. Plant Cell Physiol. 35:489-495.

Baker AJM (1981) Accumulators and excluders-strategies in the response of plants to heavy metals. J. Plant Nutr. 3: 643-654.

Bazzaz FA, Carlson RW, Rolfe GL (1975) The inhibition of corn and soybean photosynthesis by lead. Physiol. Plant. 34:326-329.

Bazzaz FA, Rolfe GL, Windle P (1974) Differing sensitivity of corn and soybean photosynthesis and transpiration to lead contamination. J. Environ. Qual. 3:156-158.

Bazzaz MB, Govindjee (1974) Effect of lead chloride on chloroplast reactions. Environ. Lett. 6:175-191.

Berry WL (1986) Plant factors in influencing the use of plant analysis as a tool for biogeochemical prospecting. In: Carlisle D, Berry WL, Kaplan IR, Watterson JR, (eds), Mineral Exploration: Biological Systems and Organic Matter, pp.13-32. Englewood Cliffs, USA.

Blaylock MJ, Salt DE, Dushenkov S, Zakarova O, Gussman C, Kapulnik Y, Ensley BD, Raskin I (1997) Enhanced accumulation of $\mathrm{Pb}$ in Indian mustard by soil-applied chelating agents. Environ. Sci. Technol. 31:860-865.

Breckle SW (1991) Growth under stress. Heavy metals. In: Waisel Y, Eshel A, Kafkafi U (eds), Plant Roots: The Hidden Half, pp. 351-373. Marcel Dekker Inc., New York, USA.

Broyer R, Johnson CM, Paull RE (1972) Some aspects of lead in plant nutrition. Plant Soil 36:301-313.

Burton KW, Morgan E, Roig A (1984) The influence of heavy metals on the growth of sitka-spruce in South Wales forests. II green house experiments. Plant Soil 78:271-282.

Burzynski M (1987) The influence of lead and cadmium on the absorption and distribution of potassium, calcium, magnesium and iron in cucumber seedlings. Acta Physiol. Plant. 9:229-238.

Burzynski M, Grabowski A (1984) Influence of lead on nitrate uptake and reduction in cucumber seedlings. Acta Soc. Bot. Pol. 53:77-86.

Chaitanya KSK, Naithani SB (1994) Role of superoxide, lipid peroxidation and superoxide dismutase in membrane perturbation during loss in viability of seeds of Shorea robusta Gaertn. F. New Phytol. 126:623-627.

Chaney RL, Ryan JA (1994) Risk based standards for arsenic lead and cadmium in urban soils. Dechema, Frankfurt, Germany. 
Chen J, Zhou J, Goldsbroubh PB (1997) Characterization of phytochelatin synthase from tomato. Physiol. Plant. 101: $165-172$

Cobbett CS (2000) Phytochelatin biosynthesis and function in heavy-metal detoxification. Curr. Opin. Plant Biol. 3: 211-216.

Cunningham SD, Berti WR, Huang JW (1995) Phytoremediation of contaminated soils. Trends Biotechnol. 13:393-397.

Davies BE (1995) Lead and other heavy metals in urban areas and consequences for the health of their inhabitants. In: Majumdar SK, Miller EW, Brenner FJ (eds), Environmental Contaminants, Ecosystems and Human Health, pp.287-307. The Pennsylvania Academy of Science, Easton PA, USA.

de Abreu CA, de Abreu MF and de Andrade JC (1998) Distribution of lead in the soil profile evaluated by DTPA and Mehlich-3 solutions. Bragantia 57:185-192.

Denny P and Weeks DC (1968) Electropotential gradients of ions in an aquatic angiosperm Potamegeton schweinfurthii (Benn). New Phytol. 67:875-882.

Drazkiewicz M (1994) Chlorophyll-occurrence, functions, mechanism of action, effects of internal and external factors. Photosynthetica 30:321-331.

Dushenkov V, Kumar PBAN, Motto H, Raskin I (1995) Rhizofiltration: the use of plants to remove heavy metals from aqueous stream. Environ. Sci. Technol. 29:1239-1245.

Eick MJ, Peak JD, Brady PV, Pesek JD (1999) Kinetics of lead adsorption and desorption on goethite: Residence time effect. Soil. Sci. 164:28-39.

Ernst WHO (1980) Biochemical aspects of cadmium in plants. In: Nriagu JO (ed), Cadmium in the Environment, pp.639-653. J Wiley and Sons, New York, USA.

Ernst WHO (1998) Effects of heavy metals in plants at the cellular and organismic levels. In: Schuurmann G (ed), Ecotoxicology: Ecological Fundamentals, Chemical Exposure and Biological Effects, pp. 587-620. Heidelberg, Wiley.

Eun SO, Youn HS, Lee Y (2000) Lead disturbs microtubule organization in the root meristem of Zea mays. Physiol. Plant. 110:357-365.

Farago ME, Mullen WA (1979) Plants which accumulate metals. Part IV. A possible copper-proline complex from the roots of Armeria maritima. Inorg. Chim. Acta 32: L93-L94.

Foyer CH, Lopez-Delgado H, Dat JF, Scott IM (1997) Hydrogen peroxide and glutathione associated mechanisms of acclimatory stress and tolerance and signaling. Physiol. Plant. 100:241-254.

Frugoli JA, Zhang HH, Nuccio ML, McCourt P, McPeak MA, Thomas TI, McClung CR (1996) Catalase is encoded by a multigene family in Arabidopsis thaliana (L.) Heynh. Plant Physiol. 112:327-336.

Gaspar T, Penel C, Thrope T, Greppin H (1982) Peroxidases (1970-1980). A survey of their biochemical and physiological roles in higher plants, pp. 324-330. University of Geneva Press, Centre de Botanique, Geneva, Switzerland.
Girroti AW (1990) Photodynamic lipid peroxidation in biological systems. Photochem. Photobiol. 51:497-509.

Godbold DL, Kettner C (1991) Lead influences root growth and mineral nutrition of Picea abies seedlings. J. Plant Physiol. 139:95-99.

Godzik B (1993) Heavy metal contents in plants from zinc dumps and reference area. Pol. Bot. Stud. 5:113-132.

Grill E, Winnacker EL, Zenk MH (1987) Phytochelatins, a class of heavy- metal- binding peptides of plants are functionally analogous to metallothioneins. Proc. Natl. Acad. Sci. USA 84:439-443.

Halliwell B, Gutteridge JMC (1999) Free Radicals in Biology and Medicine. $3^{\text {rd }}$ edn. Oxford University Press, New York.

Hampp R, Ziegler H, Ziegler I (1973) Influence of lead ions on the activity of enzymes of reductive pentose phosphate pathway. Biochem. Physiol. Pflanzen. 164:588-595.

Haussling M, Jorns CA, Lehmbecker G, Hecht-Buchholz C, Marschner H (1988) Ion and water uptake in relation to root development of Norway spruce (Picea abies (L.) Karst). J. Plant Physiol. 133:486-491.

Hertwig B, Streb P, Feierabend J (1992) Light dependence of catalase synthesis and degradation in leaves and the influence of interfering stress conditions. Plant Physiol. 100:1547-1553.

Huang JW, Chen J, Berti WR, Cunningham SD (1997) Phytoremediation of lead-contaminated soil: role of synthetic chelates in lead phytoextraction. Environ. Sci. Technol. 31:800-805.

Huang JW, Cunningham SD (1996) Lead Phytoextraction: species variation in lead uptake and translocation. New Phytol. 134:75-84.

Huang JW, Grunes DL, Kochian LV (1994) Voltage dependent $\mathrm{Ca}^{2+}$ influx into right-side-out plasmamembrane vesicles isolated from wheat roots: characteristic of a putative $\mathrm{Ca}^{2+}$ channel. Proc. Natl. Acad. Sci. USA 91:3473-3477.

Igoshina TI, Kositsin AV (1990) The tolerance to lead of carbonic anhydrase from Melica nutans (Poaceae). Bot. Zh. (Lenningrad) 75:1144-1150.

Iqbal J, Mushtaq S (1987) Effect of lead on germination, early seedling growth, soluble protein and acid phosphatase content in Zea mays. Pak. J. Sci. Ind. Res. 30:853-856.

Jana S, Choudhari MA (1982) Senescence in submerged aquatic angiosperms: effects of heavy metals. New Phytol. 90:477- 484.

Jarvis MD, Leung DWM (2002) Chelated lead transport in Pinus radiata: an ultrastructural study. Environ. Exp. Bot. 48:21-32.

Johnson MS, Eaton JW (1980) Environmental contamination through residual trace metal dispersal from a derelict lead-zinc mine. J. Environ. Qual. 9:175-179.

Jones LHP, Clement CR, Hopper MJ (1973) Lead uptake from solution by perennial ryegrass and its transport from roots to shoots. Plant Soil 38:403-414. 
Kabata-Pendias A, Pendias H (1992) Trace elements in soils and plants. $2^{\text {nd }}$ edn. CRC Press, Boca Raton, London.

Koeppe D E (1977) The uptake, distribution and effect of cadmium and lead in plants. Sci. Total Environ. 7:197-205.

Koeppe DE, Miller RJ (1970) Lead effects on corn mitochondrial respiration. Science 167:1376-1377.

Kosobrukhov A, Knyazeva I, Mudrik V (2004) Plantago major plants responses to increase content of lead in soil: growth and photosynthesis. Plant Grow Regul. 42:145-151.

Kroschwitz JI (1995) Iron compounds. In: Kroschwitz JI (ed), Kirk-Othmer Encyclopedia of Chemical Technology, Ed 4, pp. 887-888. John Wiley and Sons, New York, USA.

Ksiazek M, Wozny A, Mlodzianowski F (1984) Effect of $\mathrm{Pb}\left(\mathrm{NO}_{3}\right)_{2}$ on poplar tissue culture and the ultrastructural localization of lead in culture cells. For. Ecol. Manag. 8:95-105.

Kumar NPBA, DushenkovV, Motto H, Raskin I (1995) Phytoextraction: the use of plants to remove heavy metals from soils. Environ. Sci. Technol. 29:1232-1238.

Lamoreaux RJ, Chaney WR (1978) The effect of cadmium on net photosynthesis, transpiration and dark respiration of excised silver maple leaves. Physiol. Plant. 43:231-236.

Lane SD, Martin ES (1977) A histochemical investigation of lead uptake in Raphanus sativus. New Phytol. 79:281-286.

Laxen DPH, Harrison RM (1977) The highway as a source of water pollution: an appraisal of heavy metal lead. Water Res. 11:1-11.

Lee KC, Cunningham BA, Poulsen GM, Liang JM, Moore RB (1976) Effects of cadmium on respiration rate and activities of several enzymes in soybean seedlings. Physiol. Plant. 36:4-6.

Lee S-Z, Chang L, Yang H-H, Chen C-M, Liu M-C (1998) Absorption characteristics of lead onto soils. J. Haz. Mat. 63:37-49.

Levina EN (1972) Obshchaya tosikologiya metallov (General metal toxicology). Leningrad, Meditsyna.

Lozano R, Azcon R, Palma JM (1996) SOD and drought stress in Lactua sativa. New Phytol. 136:329-331.

Maitra P, Mukherji S (1977) Effect of lead on nucleic acid and protein contents of rice seedlings and its interaction with IAA and $\mathrm{GA}_{3}$ in different plant systems. Ind. J. Exp. Biol. 17:29-31.

Malkowski E, Kita A, Galas W, Karez W, Michael K (2002) Lead distribution in corn seedlings (Zea mays L.) and its effect on growth and the concentration of potassium and calcium. Plant Growth Regul. 37:69-76.

Marschner P, Godbold DL, Jutschhe G (1996) Dynamics of lead accumulation in mycorrhizal and non-mycorrhizal Norway spruce (Picea abies (L.) karst.). Plant Soil 178:239-245.

Marshall J, Corzo A, Leigh RA, Sanders D (1994) Membrane potential-dependent calcium transport in right-side-out plasma membrane vesicles from Zea mays L. roots. Plant J. 5:683-694.

Mehta SK, Gaur JP (1999) Heavy metal induced proline accumulation and its role in ameliorating metal toxicity in Chlorella vulgaris. New Phytol. 143:253-259.

Michalak E, Wierzbicka M (1998) Differences in lead tolerance between Allium cepa plants developing from seeds and bulbs. Plant Soil 199:251-260.
Miles CD, Brandle JR, Daniel DJ, Chu-Der O, Schnare PD, Uhlik DJ (1972) Inhibition of PS II in isolated chloroplasts by lead. Plant Physiol. 49:820-825.

Miller RJ, Biuell JE, Koeppe DE (1973) The effect of cadmium on electron and energy transfer reactions in corn mitochondria. Physiol. Plant. 28:166-171.

Miller RJ, Koeppe DE (1971) Accumulation and physiological effects of lead in corn. In: Proceedings of University of Missouri, Columbia 4, pp.186-193.

Mishra A, Choudhari MA (1998) Amelioration of lead and mercury effects on germination and rice seedling growth by antioxidants. Biol. Plant. 41:469-473.

Mohanty N, Vass I, Demeter S (1989) Copper toxicity affects Photosystem II electron transport at the secondary quinone acceptor, $\mathrm{Q}_{\mathrm{B}}$. Plant Physiol. 90:175-179.

Morel JL, Mench M, Guckert A (1986) A measurement of Pb, $\mathrm{Cu}, \mathrm{Cd}$ binding with mucilage exudates from maize (Zea mays L.) roots. Biol. Fertil. Soils 2:29-34.

Moustakas M, Lanaras T, Symeonidis L, Karataglis S (1994) Growth and some photosynthetic characteristics of field grown Avena sativa under copper and lead stress. Photosynthetica 30:389-396.

Mukherji S, Maitra P (1976) Toxic effects of lead on growth and metabolism of germinating rice (Oryza sativa L.) root tip cells. Ind. J. Exp. Biol. 14:519-521.

Obroucheva NV, Bystrova EI, Ivanov VB, Anupova OV, Seregin IV (1998) Root growth responses to lead in young maize seedlings. Plant Soil 200:55-61.

Paivoke AEA (2002) Soil lead alters phytase activity and mineral nutrient balance of Pisum sativum. Environ. Exp. Bot. 48:61-73.

Paleg LG, Stewart GR, Bradbeer JW (1984) Proline and glycine betaine influence on protein solvation. Plant Physiol. 75:974-978.

Parys E, Romanowaska E, Siedlecka M, Poskuta J (1998) The effect of lead on photosynthesis and respiration in detached leaves and in mesophyll protoplasts of Pisum sativum. Acta Physiol. Plant. 20:313-322.

Pinto E, Sigaud-Kutner TCS, Leitao AS, Okamoto OK, Morse D, Coilepicolo P (2003) Heavy-metal induced oxidative stress in algae. J. Phycol. 39:1008-1018.

Poskuta JW, Parys E, Romanowaska E (1996) Toxicity of lead to photosynthesis, accumulation of chlorophyll, respiration and growth of Chlorella pyrenoidosa. Protective role of dark respiration. Acta Physiol. Plant. 18:165-171.

Prassad DDK, Prassad ARK (1987) Altered $\delta$-aminolaevulinic acid metabolism by lead and mercury in germinating seedlings of Bajra (Pennisetum typhoideum). J. Plant Physiol. 127:241-249.

Przymusinski R, Rucinska R, Gwozdz EA (1995) The stress stimulated $16 \mathrm{Kda}$ polypeptide from Lupin roots has properties of cytosolic $\mathrm{Cu}$ : Zn-superoxide dismutase. Environ. Exp. Bot. 35:485-495.

Przymusinski R, Spychala M, Gwozdz EA (1991) Inorganic lead changes growth polypeptide pattern of lupin roots. Biochem. Physiol. Pflan. 187:51-57.

Quereshi JA, Hardwick K, Collin HA (1986) Intracellular localization of lead in a lead tolerant and sensitive clone of Anthoxanthu odoratum. J. Plant Physiol. 122:357-364. 
Rashid A, Bernier M, Pazdernick L, Carpentier L (1991) Interaction of $\mathrm{Zn}^{2+}$ with the donor side of Photosystem II. Photosynth. Res. 30:123-130.

Rashid A, Camm EL, Ekramoddoullah KM (1994) Molecular mechanism of action of $\mathrm{Pb}$ and $\mathrm{Zn}^{2+}$ on water oxidizing complex of photosystem II. FEBS Lett. 350:296-298.

Rashid P, Mukherji S (1991) Changes in catalase and ascorbic oxidase activities in response to lead nitrate treatments in mungbean. Ind. J. Plant Physiol. 34:143-146.

Raskin I, Kumar NPBA, Dushenkov S, Salt DE (1994) Bioconcentration of heavy metals by plants. Curr. Opin. Biotech. 5:285-290.

Raven JA, Evans MCW, Korb RE (1999) The role of trace metals in photosynthetic electron transport in $\mathrm{O}_{2}$-evolving organisms. Photosynth. Res. 60:111-149.

Rebechini HM, Hanzely L (1974) Lead-induced ultrastructural changes in chloroplasts of the hydrophyte Ceratophyllum demersum. Z. Pflanzenphysiol. 73:377-386.

Reese RN, Roberts LW (1985) Effects of cadmium on whole cell and mitochondrial respiration in tobacco cell suspension cultures (Nicotiana tobacum L. var. xanthi). J. Plant Physiol. 120:123-130.

Reeves RD, Brooks RR (1983) European species of Thlaspi L. (Cruciferae) as indicators of nickel and zinc. J. Geochem. Explor. 18:275-283.

Romanowska E, Igamberdiev AU, Parys E, Gardeström $\mathrm{P}$ (2002) Stimulation of respiration by $\mathrm{Pb}$ in detached leaves and mitochondria of $\mathrm{C}_{3}$ and $\mathrm{C}_{4}$ plants. Physiol. Plant. 116:148-154.

Rudakova EV, Karakis KD, Sidorshina ET (1988) The role of plant cell walls in the uptake and accumulation of metal ions. Fiziol. Biochim. Kult. Rast. 20:3-12.

Salt DE, Blaylock M, Kumar PBAN, Dushenkov V, Ensley BD, Chet I, Raskin I (1995) Phytoremediation: a novel strategy for the removal of toxic metals from the environment using plants. Biotechnology 13:468-475.

Samardakiewicz S, Wozny A (2000) The distribution of lead in duckweed (Lemna minor L.) root tip. Plant Soil 226:107-111.

Sarvari E, Gaspar L, Fodor F, Cseh E, Kropfl K, Varga A, Baron M (2002) Comparison of the effects of effects of $\mathrm{Pb}$ treatment on thylakoid development in poplar and cucumber plants. Acta Biol. Szeged. 46:163-165.

Sengar RS, Pandey M (1996) Inhibition of chlorophyll biosynthesis by lead in greening Pisum sativum leaf segments. Biol. Plant. 38:459-462.

Seregin IV, Ivaniov VB (1997) Histochemical investigation of cadmium and lead distribution in plants. Fiziol. Rast. 44:915-921.

Seregin IV, Ivaniov VB (2001) Physiological aspects of cadmium and lead toxic effects on higher plants. Russ. J. Plant Physiol. 48:606-630.

Seregin IV, Shpigun LK, Ivaniov VB (2004) Distribution and toxic effects of cadmium and lead on maize roots. Russ. J. Plant Physiol. 51:525-533.
Sersen F, Kralova K, Bumbalova A (1998) Action of mercury on the photosynthetic apparatus of spinach chloroplasts. Photosynthetica 35:551-559.

Sharma P, Dubey RS (2004) Ascorbate peroxidase from rice seedlings: properties of enzyme isoforms, effects of stresses and protective roles of osmolytes. Plant Sci. 167:541-550.

Sieghardt H (1988) Schwermetall- und Nahrelementgehalte von Pflazen und Bodenproben schwermetallhaltiger Halden im Raum Bleiberg in Karnten (Osterreich). II. Holzpflazen. Z. Pflazenenernahr. Bodenk 151:21-26.

Silverberg BA (1975) Ultrastructural localization of lead in Stigeoclonium tenue (Chlorophyseae Ulotrichales) as demonstrated by cytochemical and X-ray microanalysis. Phycologia 14:265-274.

Stefanov K, Popova I, Kamburova E, Pancheva T, Kimenov G, Kuleva L, Popov S (1993) Lipid and sterol changes in Zea mays caused by lead ions. Phytochemistry 33:47-51.

Stefanov K, Seizova K, Popova I, Petkov VL, Kimenov G, Popov S (1995) Effects of lead ions on the phospholipid composition in leaves of Zea mays and Phaseolus vulgaris. J. Plant Physiol. 147:243-246.

Subhashini K, Reddy GM (1990) Effect of salt stress on enzyme activities in callus cultures of tolerant and susceptible rice cultivars. Ind. J. Exp. Biol. 28:277-279.

Suchodoller A (1967) Untersuchungen uber den Bleigehatt von Pflanzen in der Nane von Strassen und uber die Aufnahme and Translokation von Blei durch Pflazen. Berichteder Schweizerischen Botanischen Gesellschaft 77:266-308.

Tomsig JL, Suszkiw JB (1991) Permeation of Pb through calcium channels: fura- 2 measurements of voltage- and dihydropyridine-sensitive $\mathrm{Pb}$ entry in isolated bovine chromaffin cells. Biochim. Biophys. Acta 1069:197-200.

Tu Shu I, Brouillette JN (1987) Metal ion inhibition of corn root plasmamembrane ATPase. Phytochemistry 26:65-69.

Tung G, Temple PJ 1996 Uptake and localization of lead in corn (Zea mays L.) seedlings: a study by histochemical and electron microscopy. Sci. Total Environ. 188:71-85.

Vallee BL, Ulmer DD (1972) Biochemical effects of mercury, cadmium and lead. Annu. Rev. Biochem. 41:91-128.

van Assche F, Clijsters H (1990) Effects of metal on enzyme activity in plants. Plant Cell Environ. 13:195-206.

Vassil AD, Kapulnik Y, Raskin I, Salt DE (1998) The role of EDTA in lead transport and accumulation by Indian mustard. Plant Physiol. 117:447-453.

Verma S, Dubey RS (2003) Lead toxicity induces lipid peroxidation and alters the activities of antioxidant enzymes in growing rice plants. Plant Sci. 164:645-655.

Vodnik D, Jentschke G, Fritz E, Gogala N, Godbold DL (1999) Root-applied cytokinin reduces lead uptake and affects its distribution in Norway spruce seedlings. Physiol. Plant. 106:75-81.

Vojtechova M, Leblova S (1991) Uptake of lead and cadmium by maize seedlings and the effect of heavy metals on the activity of phosphoenolpyruvate carboxylase isolated from maize. Biol. Plant. 33:386-394. 
Walker WM, Miller JE, Hassett JJ (1977) Effect of lead and cadmium upon the calcium, magnesium, potassium and phosphorus concentration in young corn plants. Soil Sci. 124:145-151.

Wierzbicka M (1987) Lead accumulation and its translocation in roots of Allium cepa L. -autoradiographic and ultrastructural studies. Plant Cell Environ. 10:17-26.

Wierzbicka M (1994) Resumption of mitotic activity in Allium cepa root tips during treatment with lead salts. Environ. Exp. Bot. 34:173-180.

Wierzbicka M (1998) Lead in the apoplast of Allium cepa L. root tips-ultra structural studies. Plant Sci. 133:105-119.

Wierzbicka M, Antosiewicz D (1993) How lead can easily enter the food chain - a study of plant roots. Sci. Total Environ. Suppl. 1:423-429.
Wozny A, Zatorska B, Mlodzianowski F (1982) Influence of lead on the development of lupin seedlings and ultrastructural localization of this metal in the roots. Acta Soc. Bot. Pol. 51:345-351.

Yang Y-Y, Jung J-Y, Song W-Y, Suh HS, Lee Y (2000) Identification of rice varieties with high tolerance or sensitivity to lead and characterization of the mechanism of tolerance. Plant Physiol. 124:1019-1026.

Ye ZH, Baker AJM, Wong MH, Willis AJ (1997) Zinc, lead and cadmium tolerance, uptake and accumulation in populations of Typha latifolia L. New Phytol. 136: 469-480.

Zenk MH (1996) Heavy metal detoxification. Curr. Opin. Plant Biol. 3:211-216. 